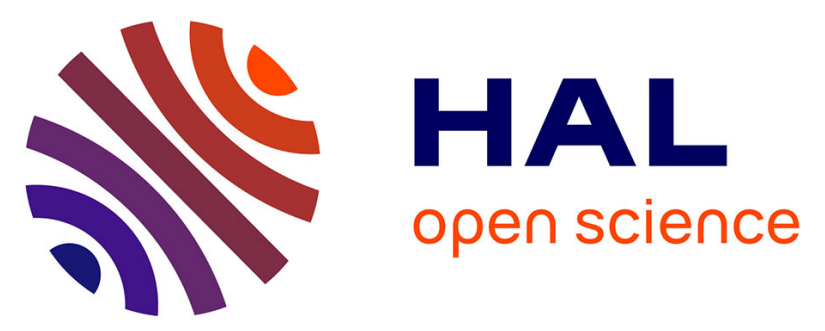

\title{
Functionalized Mesoporous Silica Nanoparticle with Antioxidants as a New Carrier That Generates Lower Oxidative Stress Impact on Cells
}

Raymond Ebabe Elle, Saher Rahmani, Céline Lauret, Marion Morena, Luc Philippe Régis Bidel, Abdelhay Boulahtouf, Patrick Balaguer, Jean-Paul Cristol, Jean-Olivier Durand, Clarence Charnay, et al.

\section{To cite this version:}

Raymond Ebabe Elle, Saher Rahmani, Céline Lauret, Marion Morena, Luc Philippe Régis Bidel, et al.. Functionalized Mesoporous Silica Nanoparticle with Antioxidants as a New Carrier That Generates Lower Oxidative Stress Impact on Cells. Molecular Pharmaceutics, 2016, 13 (8), pp.2647 - 2660. 10.1021/acs.molpharmaceut.6b00190 . hal-01817669

\section{HAL Id: hal-01817669 \\ https://hal.umontpellier.fr/hal-01817669}

Submitted on 19 Mar 2020

HAL is a multi-disciplinary open access archive for the deposit and dissemination of scientific research documents, whether they are published or not. The documents may come from teaching and research institutions in France or abroad, or from public or private research centers.
L'archive ouverte pluridisciplinaire HAL, est destinée au dépôt et à la diffusion de documents scientifiques de niveau recherche, publiés ou non, émanant des établissements d'enseignement et de recherche français ou étrangers, des laboratoires publics ou privés. 


\title{
Functionalized Mesoporous Silica Nanoparticle with Antioxidants as a New Carrier That Generates Lower Oxidative Stress Impact on Cells
}

\author{
Raymond Ebabe Elle, ${ }^{\dagger}$ Saher Rahmani, ${ }^{\ddagger}$ Céline Lauret, ${ }^{\dagger}$ Marion Morena, ${ }^{\dagger}$ Luc Philippe Régis Bidel, ${ }^{\S}$ \\ Abdelhay Boulahtouf," Patrick Balaguer," Jean-Paul Cristol, ${ }^{\dagger}$ Jean-Olivier Durand," Clarence Charnay, \\ and Eric Badia ${ }^{*} \dagger$
}

\begin{abstract}
${ }^{\dagger}$ PhyMedExp, Université de Montpellier, INSERM U1046, CNRS UMR 9214, 34295 Montpellier cedex 5, France
${ }^{\ddagger}$ Institut Charles Gerhardt de Montpellier (ICGM), CNRS UMR 5253, Université de Montpellier, Campus Triolet, Place Eugène Bataillon, 34095 Montpellier Cedex 5, France

${ }^{\S}$ INRA, UMR AGAP, Centre de Recherche de Montpellier, 2 Place Pierre Viala-Bât. 21, 34060 Montpellier, France

"IRCM, Institut de Recherche en Cancérologie de Montpellier; INSERM, U1194; ICM Val d'Aurelle Paul Lamarque, Montpellier F-34298, France
\end{abstract}

\begin{abstract}
Mesoporous silica nanoparticles (MSNs) were covalently coated with antioxidant molecules, namely, caffeic acid (MSN-CAF) or rutin (MSN-RUT), in order to diminish the impact of oxidative stress induced after transfection into cells, thus generating safer carriers used for either drug delivery or other applications. Two cellular models involved in the entry of NPs in the body were used for this purpose: the intestinal Caco- 2 and the epidermal HaCaT cell lines. Rutin gave the best results in terms of antioxidant capacities preservation during coupling procedures, cellular toxicity alleviation, and decrease of ROS level after $24 \mathrm{~h}$ incubation of cells with grafted nanoparticles. These protective effects of rutin were found more pronounced in $\mathrm{HaCaT}$ than in Caco-2

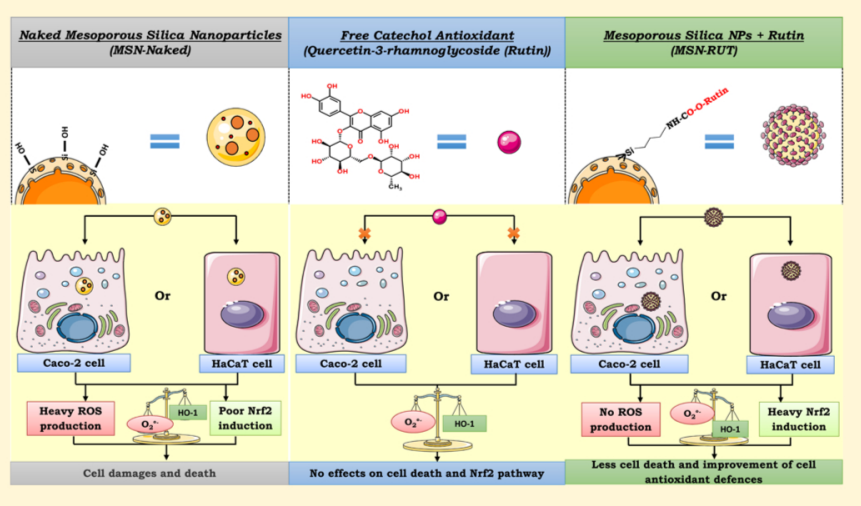
cells, indicating some cellular specificity toward defense against oxidative stress. In order to gain more insight about the Nrf2 response, a stable transfected HaCaT cell line bearing repeats of the antioxidant response element (ARE) in front of a luciferase reporter gene was generated. In this cell line, both tBHQ and quercetin (Nrf2 agonists), but not rutin, were able to induce, in a dose-dependent fashion, the luciferase response. Interestingly, at high concentration, MSN-RUT was able to induce a strong Nrf2 protective response in $\mathrm{HaCaT}$ cells, accompanied by a comparable induction of HO-1 mRNA. The level of these responses was again less important in Caco- 2 cells. To conclude, in keratinocyte cell line, the coupling of rutin to silica nanoparticles was beneficial in term of ROS reduction, cellular viability, and protective effects mediated through the activation of the Nrf2 antioxidant pathway.
\end{abstract}

KEYWORDS: mesoporous silica nanoparticle, catechol antioxidant, Nrf2, Caco-2 cell line, HaCaT cell line, antioxidative response

\section{INTRODUCTION}

Due to their small size and their large functional surfaces, nanoparticles (NPs) and the nanobio interface have unique properties compared to their larger counterparts. ${ }^{1-5}$ In recent years, the production of engineered nanoparticles worldwide has increased a lot as a response to an exponential growth in the development of nanotechnologies. Silica NPs are the fourth most used nanomaterial listed in nanotechnology consumer products inventory. ${ }^{6}$ Indeed, they have great practical importance in many industrial applications from cosmetic and pharmaceutical sciences to manufactured food products. For example, they are already used as anticaking agent, in powdered food products such as salt and sugar, or as fluidizer in industrial sauces, in the form of some additive. Mesoporous silica nanoparticles (MSNs) are also widely used as catalyst support and in biomedical applications for biomolecule detection ${ }^{7-9}$ or as effective theranostic platforms for emergent therapies. ${ }^{10-17}$ There is increasing research intended to use MSNs as drug delivery systems because, compared to other polymer drug carriers, MSNs are more resistant to mechanical stress, heat, $\mathrm{pH}$, and hydrolysis-induced degradations. Furthermore, they have a high surface area and a large pore volume that allows high loading of drug molecules. ${ }^{18}$ Therefore, MSNs are ideal candidates for providing entities capable to store first and gradually release therapeutically relevant drugs. ${ }^{19-21}$ Due to 
their small size, nanoparticles can be captured by cells and then distributed in different cellular substructures. ${ }^{22}$ They were found to deposit mainly in cytoplasm and endosomes, ${ }^{22}$ but silica nanoparticles were also found to deposit in mitochondria, lysosomes, or autophagosomes. ${ }^{23,24}$ Conversely, the possibility for silica mesoporous nanoparticles of being released from cells by exocytosis have also been described. ${ }^{18}$

Biomedical research on mesoporous silica nanoparticles has rapidly gained interest, due to their exceptional properties. Indeed, their high surface area and easy pore size control made them good candidates for drug or enzymes delivery. ${ }^{25,26}$ However, as it is the case for most types of nanoparticles, they elicit cytotoxic effects per se that may be partly due to the ROS generation that alters membrane integrity, cell metabolism, and apoptotic signaling. ${ }^{27,28}$ Indeed, numerous studies demonstrated that nanoparticles induced toxicological effects on various tissues such as lung, liver, kidneys, and spleen. ${ }^{29,30}$ In consequence, many strategies have been developed in the field of nanotoxicology ${ }^{31}$ to analyze and counteract these adverse effects. First, by taking advantage of the porosity of nanoparticles, it is possible to combine them noncovalently with antioxidant molecules or enzymes. However, such strategies that have been used by several authors were in principle intended to deliver antioxidant molecules to the cell. $^{32-37}$ As an example, in the case of rutin, its poor solubility led to imagine new nanoparticle-based drug-delivery as a solution to improve parental or topical bioavailability. ${ }^{38}$

An important question that has emerged from different studies concerns the involvement of ROS in nanoparticles cytotoxicity. However, if ROS generation has been observed after treatment with nanoparticles, both in vitro and in vivo, its relationship with cytotoxicity is far from clear. ${ }^{39-42}$ Indeed, we still do not know if ROS production is the first event and cytotoxicity would be a consequence of such production, or if the reverse is the right concept. ${ }^{43,44}$ Excessive amount of ROS leads to deleterious oxidation of proteins, lipids, and DNA, underlying many pathologies. ${ }^{45}$ Furthermore, McCarthy et al. ${ }^{46}$ demonstrated that toxicity induced by amorphous silica nanoparticles can be decreased by an antioxidant treatment, suggesting the crucial role of oxidative stress in this injury.

In order to prevent damages due to oxidative stress, antioxidant enzymes are specifically induced thanks to the action of the nuclear erythroid related factor $2(\mathrm{Nrf} 2)$, which is a transcription factor involved in the regulation of cellular antioxidative responses and redox status. ${ }^{47}$ These include gluthatione (GSH), gluthatione S-transferases (GSTs), heme oxygenase 1 ( $\mathrm{HO}-1), \mathrm{NAD}(\mathrm{P}) \mathrm{H}$ quinone oxidoreductase 1 (NQO1), thioredoxin, and some other proteins involved in ROS scavenging. At the basal state, Nrf2 localizes in the cytoplasm and is constantly degraded via the ubiquitin proteasome pathway, in a Kelch-like ECH associating protein 1 (Keap1)-dependent manner. ${ }^{48,49}$ The Keap1-Nrf2 pathway can be activated by ROS or electrophilic agents ${ }^{50}$ and also by various types of phytochemicals polyphenols that are present in food. ${ }^{51}$ Such activation leads to the dissociation of Nrf2 from Keap1, allowing Nrf2 factor to translocate to the nucleus, bind to the antioxidant response element (ARE), and transactivate antioxidant target genes. The stimulation of the Keap1-Nrf2 pathway leads to manifold aspects of cytoprotection such as neuroprotection, anticarcinogenicity, antiangiogenesis, and antiapoptosis. $^{52}$ Moreover, total and mitochondrial ROS production in $\mathrm{Nrf2}-\mathrm{KO}$ cells and tissues was increased dramatically in comparison with their wild-type counterparts. ${ }^{53}$
Based on these knowledges, we investigated the influence of surface functionalization of MSNs with antioxidants moieties, on cytotoxicity and ROS production in cells. MSNs were functionalized with two phenolic antioxidants: either a flavonoid, rutin (quercetin-3-O-[ $\alpha$-L-rhamnosyl- $(1 \rightarrow 6)-\beta$-Dglucopyranoside]) found in fruits such as orange and lemon, or caffeic acid, found in some herbs such as thyme and sage. Multiple beneficial effects of flavonoid consumption on health were evidenced. ${ }^{54,55}$ Indeed, mainly due to the presence of the ortho- and meta-hydroxyl groups of the catechol structure, these phenolics are able to scavenge or donate hydrogen atoms to free radical in order to prevent ROS formation and biological damages. ${ }^{56,57}$ In addition, rutin acts as metallic chelator and binds to the iron ion $\mathrm{Fe}^{2+}$, preventing it from binding to hydrogen peroxide, which would otherwise create a highly reactive free radical that may damage cells. ${ }^{58}$

We evaluated the effects of functionalized or free MSNs on two cellular models involved in the entry of NPs in the body: the intestinal Caco-2 and the epidermal HaCaT cell lines. Biological parameters evaluated in this study focused on ROS production, activation of the Keap1-Nrf2 pathway, and cell death.

\section{EXPERIMENTAL SECTION}

1. Chemicals and Materials. All solvents used were reagent grade. The following chemicals, tetraethyl orthosilicate (TEOS, 99\%), 3-aminopropyltriethoxysilane (APTES), 3isocyanatopropyltriethoxysilane, hexadecyltrimethylammonium bromide (CTAB, 95\%), sodium hydroxide $(\mathrm{NaOH}, 98 \%)$, ammonium nitrate $\left(\mathrm{NH}_{4} \mathrm{NO}_{3}\right)$, dicyclohexylcarbodiimide (DCC), diisopropylethylamine, caffeic acid (98\% HPLC), and rutin (>94\% HPLC) were purchased from Sigma-Aldrich (St Louis, MO, USA) and used without further purification.

Culture medium (DMEM F12 with or without phenol red), fetal calf serum (FCS), MEM non-essential amino acids, and insulin-transferin-selenium medium (ITS) were obtained from Life Technologies Inc. (Cergy-Pontoise, France). Penicilinsteptomycin and L-glutamine were obtained from Lonza (Verviers, Belgium). 2',7'-Dichlorofluorescein was obtained from Merck (Darmstadt, Germany). 2,2'-Azobis (2-amidinopropane) dihydrochloride (AAPH) was purchased from Polyscience (Warrington, USA). Thiazolyl blue tetrazolium bromide (MTT), 6-hydroxy-2,5,7,8-tetramethylchroman-2-carboxylic acid (Trolox), 2', $7^{\prime}$-dichlorofluorescin diacetate (DCFH $\left.\mathrm{H}_{2}-\mathrm{DA}\right)$, and ITS-G were from Sigma-Aldrich Inc. (St Louis, MO, USA). Black-walled 96-well microplates were from Fischer Scientific (Illkirch, France). White opaque 96-well tissue culture plates were from Dutscher (Brumath, France). Black-walled plates with a transparent background were from Porvair Sciences (Leatherhead, UK). For mRNA extraction and retrotranscription, kits were respectively from Qiagen (Courtabœuf, France) and Ozyme (Saint-Quentin-en-Yvelines, France). For quantitative PCR, Kappa Syber fast universal Readymix kit was from CliniSciences (Nanterre, France), and Light Cycler Real-Time PCR system was from Roche Applied Science (Meylan, France). Luminescence analysis was carried out by using the Tristar ${ }^{2}$ luminometer from Berthold (Thoiry, France).

2. Synthesis and Functionalization of Nanoparticles. MSNs were synthesized using a modified Stöber method under basic conditions making use of CTAB surfactants as structure directing agents and TEOS as a silica source. In a typical synthesis, $0.05 \mathrm{~g}$ of $\mathrm{CTAB}$ and $350 \mu \mathrm{L}$ of $\mathrm{NaOH}(2 \mathrm{M})$ were 
dissolved in $50 \mathrm{~g}$ of deionized water under constant stirring at $313 \mathrm{~K}$. TEOS $(575 \mu \mathrm{L})$ was poured into the solution, then the resulting mixture was subsequently stirred for $2 \mathrm{~h}$ at $313 \mathrm{~K}$. The resulting solid was collected by centrifugation and washed with distilled water and ethanol. In order to extract efficiently the porosity template from the nanoparticles, the solid was redispersed in a $100 \mathrm{~mL}$ round flask containing $50 \mathrm{~mL}$ of an alcoholic solution of nitrate ammonium $(6 \mathrm{~g} / \mathrm{L}$ in EtOH) and was refluxed at $80{ }^{\circ} \mathrm{C}$ for $2 \mathrm{~h}$, then at $60{ }^{\circ} \mathrm{C}$ overnight. The sample was centrifuged at $35,700 \mathrm{~g}$ for $10 \mathrm{~min}$ and washed 4 times consecutively with $30 \mathrm{~mL}$ of $\mathrm{EtOH}, 2$ times with ultrapure water, then EtOH. Each washing step involved 15 min of sonication and a centrifugation operation at $35,700 \mathrm{~g}$ for $10 \mathrm{~min}$. Finally, the sample was dried for $4 \mathrm{~h}$ in vacuum at room temperature.

Preparation of $\mathrm{MSN}-\mathrm{NH}_{2}: 200 \mathrm{mg}$ of $\mathrm{MSN}$ was put in suspension in $20 \mathrm{~mL}$ of toluene; $550 \mu \mathrm{L}$ of APTS was added to the nanoparticles suspension. The reaction was stirred at 120 ${ }^{\circ} \mathrm{C}$ for $7 \mathrm{~h}$. Nanoparticles were centrifuged (10 min at 20,000 rpm) and washed 3 times with $\mathrm{EtOH}$ and dried under vacuum.

Preparation of MSN-CAF: $60 \mathrm{mg}$ of $\mathrm{MSN}_{-} \mathrm{NH}_{2}$ was dispersed into $10 \mathrm{~mL}$ of DMF with $250 \mathrm{mg}$ of caffeic acid and $0.8 \mathrm{~g}$ of DCC at room temperature for 2 days. Then, MSNCAF particles were centrifuged $(10 \mathrm{~min}$ at $20,000 \mathrm{rpm})$ and washed 3 times with ethanol and dried under vacuum.

Preparation of MSN-RUT: The rutin was first silylated before the grafting on the MSN particles; $300 \mathrm{mg}(0.492$ $\mathrm{mmol}$ ) of rutin was reacted with isocyanatopropyltriethoxysilane $(250 \mu \mathrm{L}, 2$ equiv) and diisopropylethylamine $(7 \mu \mathrm{L})$ in THF $(20 \mathrm{~mL})$ overnight at $65^{\circ} \mathrm{C}$. Then the solvent THF was removed using a rotary evaporator. In a second step, all the silylated rutin was dissolved in $20 \mathrm{~mL}$ of EtOH, and $195 \mathrm{mg}$ of MSNs were added under vigorous agitation. The mixture was brought to boiling point and reflux for $6 \mathrm{~h}$ with stirring. Then, MSN-RUT particles were centrifuged (10 min at 20,000 rpm) and washed 3 times with ethanol and dried under vacuum.

3. Physicochemical Characterization of Functionalized Nanoparticles. Materials characterizations: Transmission electron micrographs (TEM) were obtained with a JEOL 1200 EX microscope. For the purpose of TEM analysis, the sample particles were dispersed in ethanol and then dropped onto copper grids with porous carbon films. The specific surface area and pore structure parameters of the materials studied were determined from the measurements of nitrogen adsorption-desorption at $77 \mathrm{~K}$ with the use of a Micromeritics ASAP 2020 V3.00 H unit. Prior to the sorption experiment, the sample (about $40 \mathrm{mg}$ ) was evacuated under vacuum at $523 \mathrm{~K}$ for $12 \mathrm{~h}$.

Hydrodynamic diameter and zeta potential were determined at $25{ }^{\circ} \mathrm{C}$ using a NanoZS apparatus (Malvern). Each measurement was performed in aqueous solution at $20 \mu \mathrm{g} /$ $\mathrm{mL}$ dilution NPs from a stock suspension at $10 \mathrm{mg} / \mathrm{mL}$ in EtOH 95\%. For zeta potential, the suspensions were prepared by dilution in $\mathrm{NaCl} 1 \mathrm{mM}$ in order to impose the ionic strength. Data were collected from the $\mathrm{He}-\mathrm{Ne}$ laser light source $(633 \mathrm{~nm})$ at $173^{\circ}$ from the transmitted beam.

4. Nanoparticles Stock Solution. Nanoparticle powder was sterilized by a $15 \mathrm{~min}$ bath in ethanol $100 \%$, and then centrifuged at $8000 \mathrm{~g}$ during $5 \mathrm{~min}$. Ethanol was then removed, and the resulting powder was air-dried under sterile conditions. Powder was suspended in culture medium (DMEM, without serum $(3333 \mu \mathrm{g} / \mathrm{mL})$ and sonicated until nanoparticles became dispersed.
5. Generation of Stable Reporter HaCaT-L Cell Line. Generation of the HaCaT ( $\mathrm{Nrf} 2-\mathrm{RE}_{8}$-TATA-Luc) cell line was performed by transfecting in HaCaT cells (given by Dr L Le Cam (IRCM, Montpellier, France)) a plasmid bearing eight antioxidant response elements (GTGACAAAGCA) in front of the luciferase gene driven by a TATA promoter and using hygromycin resistance as selectable marker. After incubation in the presence of $0.25 \mathrm{mg} / \mathrm{mL}$ hygromycin, several clones were obtained and their luciferase response quantified. Among them, the clone showing the highest induction factor $(( \pm) 10 \mu \mathrm{M}$ tBHQ) was chosen and amplified.

6. Cell Culture Conditions. The human epithelial colorectal adenocarcinoma cell line, Caco-2 (clone TC7) originated from Dr. D Roussey's laboratory (U178 Inserm, Villejuif, France). Cells were cultured in Dulbecco's modified Eagle medium (DMEM-F12) with penicillin (1000 U/L), streptomycin (1 $\mathrm{mg} / \mathrm{L})$, L-glutamine (4 mM), MEM nonessential amino acids (1X), supplemented with $10 \%$ FCS, and incubated at $37{ }^{\circ} \mathrm{C}$ under an atmosphere of $5 \% \mathrm{CO}_{2}$ in air. DMEM-F12 medium + penicillin + streptomycin + L-glutamine + MEM nonessential amino acids was termed MRSS.

The stably transfected human HaCaT-L cell line was routinely grown in DMEM-F12 with penicillin (1000 U/L), streptomycin $(1 \mathrm{mg} / \mathrm{L})$, hygromycine $(2.5 \mathrm{mg} / \mathrm{L})$, supplemented with $10 \%$ FCS (termed "HaCaT medium") and incubated at $37{ }^{\circ} \mathrm{C}$ under an atmosphere of $5 \% \mathrm{CO}_{2}$ in air.

7. Oxygen Radical Absorbance Capacity (ORAC). The ORAC assay that measures the peroxyl radical scavenging was performed according to the method previously reported ${ }^{59}$ with slight modifications. The 6-hydroxy-2,5,7,8-tetrametylchroman2-carboxylic acid (Trolox) was used as a reference in which results were expressed. The $2^{\prime}, 7^{\prime}$-dichlorofluorescein (DCF) stock solution $(1.94 \mathrm{M})$ was kept in the dark at $4{ }^{\circ} \mathrm{C}$. Fresh dilutions of stock solutions were performed in PBS $(10 \mathrm{mM}$ phosphate, $150 \mathrm{mM} \mathrm{NaCl}, \mathrm{pH}: 7.4)$. Test samples $(50 \mu \mathrm{L})$ or Trolox solutions $(0-20 \mu \mathrm{mol} \mathrm{L}-1)$ in addition with $100 \mu \mathrm{L}$ of $20 \mathrm{mM}$ AAPH solution and $100 \mu \mathrm{L}$ of $19.4 \mu \mathrm{M}$ DCF were added in the inner wells of a black-walled 96-well microplate. The fluorescence was recorded every $1 \mathrm{~min}$ for $100 \mathrm{~min}$ on a fluorescence microplate reader (Victor ${ }^{2}$ Wallac-PerkinElmer) at respective excitation and emission wavelengths of 485 and 535 nm. A calibration curve was generated by using a polynomial regression between times needed to obtain the $50 \%$ fluorescence decay $\left(T_{1 / 2}\right)$ and corresponding Trolox concentrations of the concentration range. Trolox equivalent antioxidant capacity of samples was calculated by reporting their corresponding $T_{1 / 2}$ on the calibration curve.

8. MTT Cytotoxicity Assay. The MTT [3-(4,5-dimethylthiazol-2-yl)-2,5-diphenyltetrazolium bromide] cytotoxicity assay was carried out on cells after a $24 \mathrm{~h}$ treatment with nanoparticles. The assay was performed either alone or after the processing of cells for the fluorescence measurement with the DCFH-DA.

9. Intracellular ROS Measurement of Caco-2 Cells Normalized with Cellular Viability. Intracellular ROS accumulation was measured by staining cells with the green fluorescent probe $\mathrm{DCFH}_{2}-\mathrm{DA}$, which is able to diffuse through the cell membrane and become enzymatically hydrolyzed by intracellular esterases to produce nonfluorescent $\mathrm{DCFH}_{2}$. Direct or indirect oxidation of $\mathrm{DCFH}_{2}$ by intracellular ROS (mainly $\mathrm{H}_{2} \mathrm{O}_{2}, \mathrm{HO}^{\circ}, \mathrm{ROO}^{\circ}, \mathrm{NO}^{\circ}$, and $\mathrm{ONOO}^{-}$) results in fluorescent DCF, which stains the cells. 
The following normalization method was developed in order to estimate the number of viable cells that generate ROS. Caco2 cells were seeded $\left(5 \times 10^{4}\right.$ cells/well $)$ in black 96-wells tissue culture plates with transparent background. Twenty-four hours later, they were rinsed two times with DMEM-F12 without phenol red and without serum (medium termed MBSS), and then were treated for $24 \mathrm{~h}$ with $(10-200 \mu \mathrm{g} / \mathrm{mL})$ dilutions of either nanoparticles (coupled or not with antioxidant molecules) or free antioxidant molecules, in a DMEM-F12 medium with no phenol red and supplemented with $1 \%$ ITS. At the end of treatment, cells were rinsed two times with DMEMF12 and preloaded with $100 \mu \mathrm{M} \mathrm{DCFH}_{2}$-DA in DMEM-F12 during $15 \mathrm{~min}$. Cells were rinsed two times with MBSS, placed in $75 \mu \mathrm{L}$ of MBSS, then production of intracellular ROS was determined as follow by using a Tristard ${ }^{2}$ spectrofluometer (Berthold) with excitation and emission wavelengths of 485 and $535 \mathrm{~nm}$, respectively. Fluorescence of DCF was recorded during $30 \mathrm{~min}$. At the end of ROS measurement, $75 \mu \mathrm{L}$ of 1 $\mathrm{mg} / \mathrm{mL}$ MTT solution were added in wells, and plates were incubated at $37^{\circ} \mathrm{C}$ during $4 \mathrm{~h}$. Medium was removed and MTT formazan crystals were dissolved in $150 \mu \mathrm{L}$ of acidified isopropanol followed by gentle agitation for $10 \mathrm{~min}$. The absorbance of converted dye was measured at $550 \mathrm{~nm}$ using a spectrophotometric microplate reader (Sunrise, TECAN, Männedorf, Swiss). The time-curve slope of the fluorescence assay was divided by the corresponding MTT value.

10. Living Cell Luciferase Assay Normalized with Cellular Viability of HaCaT-L Cells. HaCaT-L cells were seeded at a density of $5 \times 10^{4}$ cells per well, in 96-well plates (white opaque) and grown in $200 \mu \mathrm{L}$ of DMEM-F12 with $10 \%$ FCS medium. The compounds (nanoparticles or free antioxidants) to be tested were added $24 \mathrm{~h}$ later at indicated concentrations in 5\% dextran-coated charcoal-treated fetal calf serum (DCC-medium) without phenol red. The cells were then incubated for $24 \mathrm{~h}$ with selected compounds. At the end of incubation, effector containing medium was removed and replaced by $50 \mu \mathrm{L}$ of $0.3 \mathrm{mM}$ luciferin-containing culture medium. The 96-well plate was then introduced into a Tristard ${ }^{2}$ luminometer (Berthold), and intact living cell luminescence was recorded for $2 \mathrm{~s}$ and expressed as relative luminescence units (RLU).

At the end of luciferase activity measurement, $100 \mu \mathrm{L}$ of 0.75 $\mathrm{mg} / \mathrm{mL}$ MTT solution were added to wells (still containing luciferin). Plates were then incubated at $37^{\circ} \mathrm{C}$ during $4 \mathrm{~h}$ and processed as described above. The presence or absence of luciferin in the wells during MTT assay did not change significantly the values obtained and allowed an accurate determination of the living cells contained in wells that were at the origin of the luciferase activity signal. Luciferase activity of a well was then normalized by the corresponding MTT value.

11. RNA Extraction and Quantitative PCR Analysis (qPCR). Total RNA was extracted from cells using a Qiagen kit. Then, $0.5 \mu \mathrm{g}$ of total RNA was reverse transcribed using the Superscript II reverse transcriptase. Real-time quantitative Polymerase Chain Reaction (qPCR) was performed by using a Light Cycler Real-Time PCR system (Roche). Each reaction included: $2 \mu \mathrm{L}$ of Master Mix (SYBR Green), $0.5 \mu \mathrm{L}$ of each primer dilution $(10 \mu \mathrm{M}), 2.5 \mu \mathrm{L}$ of retrotranscription product (1:10 dilution), and $\mathrm{H}_{2} \mathrm{O}$ up to $10 \mu \mathrm{L}$. For each sample, results were normalized to the $18 \mathrm{~S}$ mRNA levels (reference gene).

Primers corresponding to human sequences used to assess gene expression were as follows:
$18 \mathrm{~S}$ forward: AACGAGACTCTGGCATGCTAACTA, $18 \mathrm{~S}$ reverse: CGCCACTTGTCCCTCTAAGAA;

Nrf2 forward: ACACGGTCCACAGCTCATC, Nrf2 reverse: TGTCAATCAAATCCATGTCCTG;

Keap1 forward: ATTGGCTGTGTGGAGTTGC, Keap1 reverse: CAGGTTGAAGAACTCCTCTTGC;

NQO1 forward: ATGTATGACAAAGGACCCTTCC, NQO1 reverse: TCCCTTGCAGAGAGTACATGG;

HO-1 forward: AACTTTCAGAAGGGCCAGGT, HO-1 reverse: CTGGGCTCTCCTTGTTGC.

12. Statistical Analysis. Data are shown as means \pm standard deviation (SD). Statistical analysis was performed using GraphPad Prism (San Diego,California) or Statview softwares. For Figures 3 to 5, a one-way ANOVA followed by a post hoc Bonferroni test was used to compare values. For Figures 6 and 9, a Mann-Whitney test was used to compare values of two groups of data.

Different index letters mean $p<0.05$. For Figures 4 and 5, when data were compared to the control (ITS), symbols (*) or (**) mean $p<0.05$ and $p<0.01$, respectively.

\section{RESULTS}

Coupling of Antioxidant Molecules to MSNs. A novel approach that aimed to reduce the cytotoxicity of MSNs was developed in our laboratory through the covalent grafting of two antioxidant molecules, namely, caffeic acid and rutin, onto nanoparticles. The coupling of these molecules is described in Figure 1. It was then expected that, during the cellular treatment, antioxidant moiety, by remaining attached to the nanoparticle, could help to keep a low level of ROS.

Physico-Chemical Characterization of MSNs. The synthesis routes selected for the purpose of the present study, based on the use of chain alkyltrimethylammonium surfactants as structure directing agents and TEOS as a silicon source, led to the preparation of spherical MSN particles in the colloidal range with about a $200 \mathrm{~nm}$ average diameter and exhibiting a MCM-41 type porous structure, as exemplified by TEM micrographs (Table 1, Figure 2). The $\mathrm{N}_{2}$ adsorptiondesorption $\mathrm{BET}$ confirmed the organized mesoporosity with specific surface areas of $810 \mathrm{~m}^{2} \cdot \mathrm{g}^{-1}$ and pore diameters of $3 \mathrm{~nm}$. In addition to size, shape, and textural properties of MSN, the zeta potential of the particles was characterized as this variable reflects the surface charge variation through surface modification. The naked MSN surface exhibited a zeta potential of $-30 \mathrm{mV}$ and after grafting of propylamine, caffeic acid, or rutin, the zeta potential value was increased to about $-17 \mathrm{mV}$ suggesting the neutralization of a fraction of ionizable surface groups such as silanol.

NMR and UV. In order to raise the efficiency of coupling, rutin was first reacted with the isocyanate arm and therefore coupled with naked nanoparticles. The NMR spectra displayed in the Supporting Information (Supplementary Figures S1 and S2) suggest that the coupling of rutin with (triethoxysilyl) propyl isocyanate is achieved on three different phenolic positions. Indeed, the intensity of NMR signals at $\delta=9.88$ ppm, $\delta=10.35 \mathrm{ppm}$, and $\delta=10.92 \mathrm{ppm}$ assigned to the phenolic protons $3^{\prime}, 4^{\prime}$, and $7^{60}$ are strongly decreased and shifted after rutin coupling. More precisely, hydroxyl groups of rutin that were bonded to the particle are those linked to the aromatic rings (Supplementary Figures S1 and S2), either one of those belonging to the catechol group, or one of those belonging to the diphenolic group. Concerning caffeic acid, 
A)

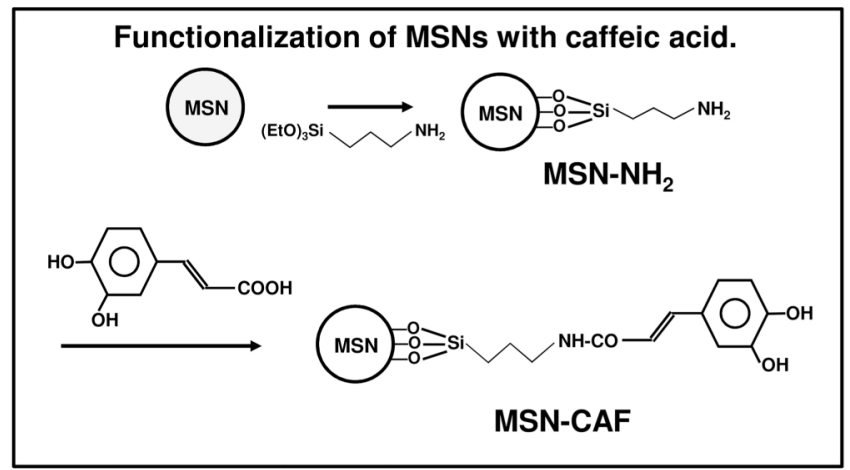

B)

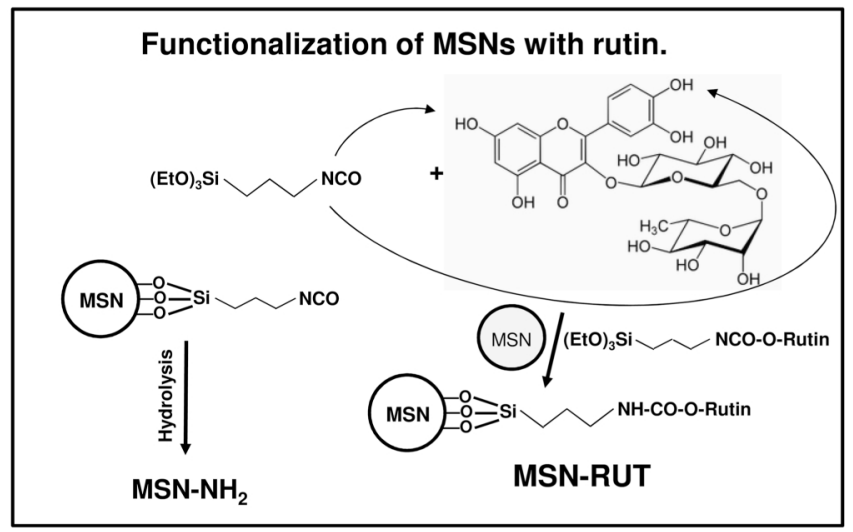

Figure 1. Diagram of nanoparticles functionalization. (A) Functionalization of nanoparticles with caffeic acid (MSN-CAF):silica nanoparticles were first functionalized with an amino-propyl derivative. Then $\mathrm{MSN}-\mathrm{NH}_{2}$ nanoparticles were linked with caffeic acid via an amide bond. (B) Functionalization of nanoparticles with rutin (MSNRUT):silica nanoparticles were first functionalized with a propylisocyanate derivative, which was previously reacted with one hydroxyl group of rutin. When MSN-RUT were dispersed in an aqueous medium, unreacted isocyanate groups were hydrolyzed, giving the same amino-propyl group as the one contained in $\mathrm{MSN}-\mathrm{NH}_{2}$.

bonding is realized through the acid function of the molecule, leaving the phenolic group free.

Another important question concerned the stability of bonded rutin onto the particles. UV spectra analysis of MSNRUT placed during $24 \mathrm{~h}$ in acidic (at $\mathrm{pH}=4.5$, similar to that of lysosomes) or neutral ( $\mathrm{pH}=7.4$ similar to the culture medium) conditions have shown a good stability of bonded rutin since only less than $5 \%$ was released from particles (Supplementary Figure S3).

Results from TGA experiments, DLS experiments (hydrodynamic diameters), zeta potentials, and specific areas of MSNNaked, are summarized in Table 1.

Radical Scavenger Properties of MSNs. Owing to catechol group of these phenolics, caffeic acid and rutin exhibit

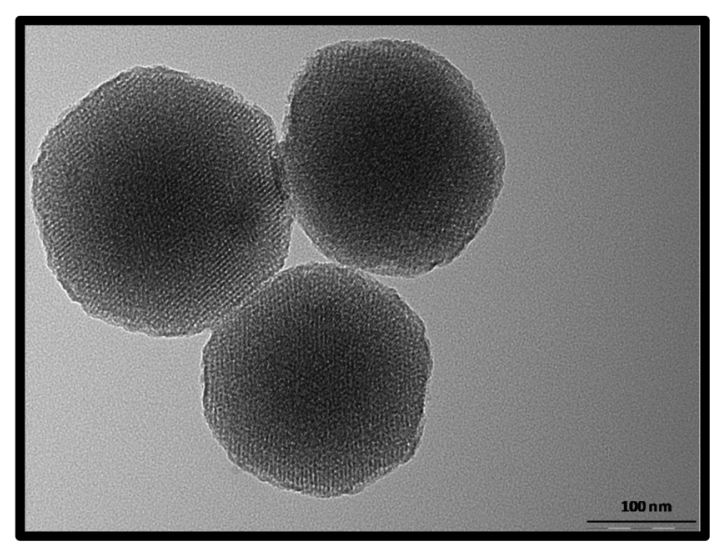

Figure 2. Transmission electron micrograph of MSNs. MSM-41 type porous structure (MSN-Naked) under TEM micrograph. Scale is indicated in the picture.

high radical scavenger properties. ${ }^{57}$ However, the inherent difficulty of such coupling procedure is that it might by itself affect antioxidant molecule properties. Antiradical properties of free or grafted antioxidant molecules were thus evaluated by using the antiradical test (ORAC). At $1 \mu \mathrm{M}$ concentration, the radical scavenger capacity of free rutin was found slightly higher, albeit not significant, than that of the same concentration of free caffeic acid (Figure 3A). We then assessed whether the antiradical capacity of these molecules was not abolished by the coupling procedures to nanoparticles. The ORAC test for MSN-CAF or MSN-RUT at $30.3 \mu \mathrm{g} / \mathrm{mL}$ indicates that both particles had a trolox equivalent level that was much higher than that of naked nanoparticles or MSN$\mathrm{NH}_{2}$ (Figure 3B) and that antiradical function of MSN-RUT was 3.7 times higher than that of MSN-CAF. In order to compare the loss of antiradical capacity due to the coupling procedures, and by using thermogravimetric data, ORAC values were calculated so as to correspond to an identical concentration $(1 \mu \mathrm{M})$ of either free or bound antioxidant (Figure 3C). One observes a substantial loss of caffeic acid antiradical capacity (98.7\%), whereas a modest reduction was observed for rutin (33\%) that could explain the high ORAC values obtained with MSN-RUT.

Cytotoxicity of Naked or Grafted MSNs. As the two main barriers before adsorption of nanoparticles are skin and intestine, we have privileged two cellular models that originate from these tissues: the Caco- 2 and $\mathrm{HaCaT}$ derived cell lines. The first one, based on an epithelial colorectal adenocarcinoma is useful to study biological effects on intestine, whereas the second one, based on a human spontaneously transformed aneuploid keratinocyte, is frequently used for the study of topical applications of chemicals on skin. ${ }^{61-63}$ As naked MSNs are known to induce oxidative stress on cells, our study focused on the degree of oxidative stress imbalance, in relation to the cytotoxicity induced by naked or antioxidant coated particles.

Table 1. Physicochemical Characterization of Nanoparticles

\begin{tabular}{|c|c|c|c|c|}
\hline & MSN-naked & MSN-NH ${ }_{2}$ & MSN-CAF & MSN-RUT \\
\hline grafted amount from TGA experiments & & $5.2 \mu \mathrm{mol} \cdot \mathrm{mg}^{-1}$ & $4.4 \mu \mathrm{mol} \cdot \mathrm{mg}^{-1}$ & $0.22 \mu \mathrm{mol} \cdot \mathrm{mg}^{-1}$ \\
\hline hydrodynamic diameter (DLS) ${ }^{a}$ & $210 \mathrm{~nm}$ & $230 \mathrm{~nm}$ & $223 \mathrm{~nm}$ & $220 \mathrm{~nm}$ \\
\hline zeta potential ${ }^{b}$ & $-30 \mathrm{mV}$ & $-17 \mathrm{mV}$ & $-22 \mathrm{mV}$ & $-19.5 \mathrm{mV}$ \\
\hline specific surface area ${ }^{c}$ & $810 \mathrm{~m}^{2} \cdot \mathrm{g}^{-1}$ & & & \\
\hline
\end{tabular}

${ }^{a}$ Determined at $25^{\circ} \mathrm{C}$ in deionized water. ${ }^{b}$ Determined at $25^{\circ} \mathrm{C}$ in $1 \mathrm{mM} \mathrm{NaCl}$ aqueous solution. ${ }^{c}$ Determined from BET mathematical treatment. 
A)

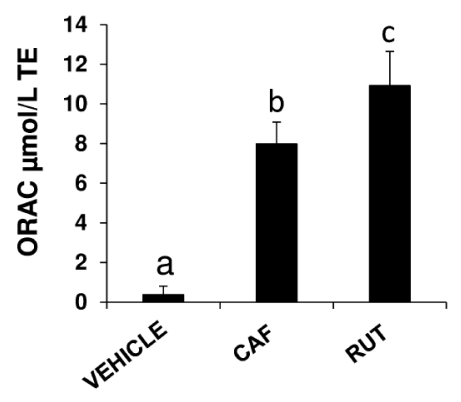

B)

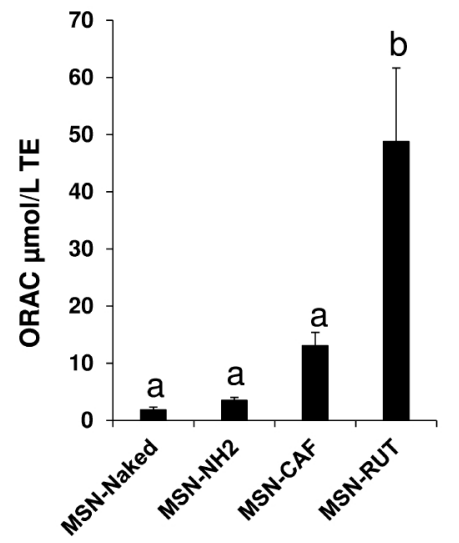

C)

\begin{tabular}{|c|c|c|}
\hline Free CAF & Bound CAF $1 \mu \mathrm{M}$ & \\
\hline $7.98 \pm 1.10$ & $0.098 \pm 0.02$ & $\mathbf{s}$ \\
\hline $\begin{array}{ll}\text { Free RUT } & 1 \mu \mathrm{M}\end{array}$ & Bound RUT $1 \mu \mathrm{M}$ & \\
\hline $10.92 \pm 1.73$ & $7.32 \pm 1.93$ & $\mathbf{s}$ \\
\hline $\mathbf{s}$ & $\mathrm{s}$ & \\
\hline
\end{tabular}

ORAC $\mu \mathrm{mol} / \mathrm{L}$ TE

Figure 3. Antiradical effect of nanoparticles (ORAC). Solutions containing (A) $1 \mu \mathrm{M}$ of free rutin (RUT), free caffeic acid (CAF), or vehicle alone, or (B) $30.3 \mu \mathrm{g} / \mathrm{mL}$ of MSN-CAF or MSN-RUT were analyzed by using ORAC assay as described in the Experimental Section. The ORAC level of samples were expressed using a unit corresponding to $\mu \mathrm{mol} / \mathrm{L}$ of trolox equivalent. (C) In this table, ORAC values were calculated so as to correspond to an identical concentration $(1 \mu \mathrm{M})$ of either free or bound antioxidant, taking into account the thermogravimetric data. Statistical analysis comparing different conditions is indicated (index letter system for A and B (see the Statistical Analysis section), or $s$ symbol $(p<0.05)$ to compare data on either a same line or a same column in table C.

Cytotoxicity of MSNs was assessed by MTT assay after a 24 $\mathrm{h}$ treatment of HaCaT-L or Caco-2 cells (Figure 4). During the period of contact of nanoparticles with cells, fetal calf serum was replaced by ITS (insulin, transferrin, and selenium) in order to increase the stability of antioxidant moieties grafted onto nanoparticles. In this context, highest concentration (200 $\mu \mathrm{g} / \mathrm{mL}$ ) of naked nanoparticles appeared clearly to be the most cytotoxic in both, the Caco- 2 and HaCaT-L cell lines, leading respectively to $69.8 \%$ and $96.4 \%$ of cellular mortality. The presence of a single amino-propyl arm bonded to nanoparticles $\left(\mathrm{MSN}-\mathrm{NH}_{2}\right)$ was sufficient to abrogate part of the cytotoxicity of such concentration of particles, leading to a percentage of mortality of $37 \%$ for $\mathrm{HaCaT}$ and $48 \%$ for Caco- 2 cells. However, the lowest concentration $(10 \mu \mathrm{g} / \mathrm{mL})$ of $\mathrm{MSN}_{-} \mathrm{NH}_{2}$ exhibited a significant degree of cytotoxicity (27.3\% of cellular mortality for Caco-2 and $25 \%$ for $\mathrm{HaCaT}$ cells) when compared to the ITS control. MSN-CAF cytotoxicity was not very different than that of $\mathrm{MSN}-\mathrm{NH}_{2}$ (albeit about $10 \%$
A)
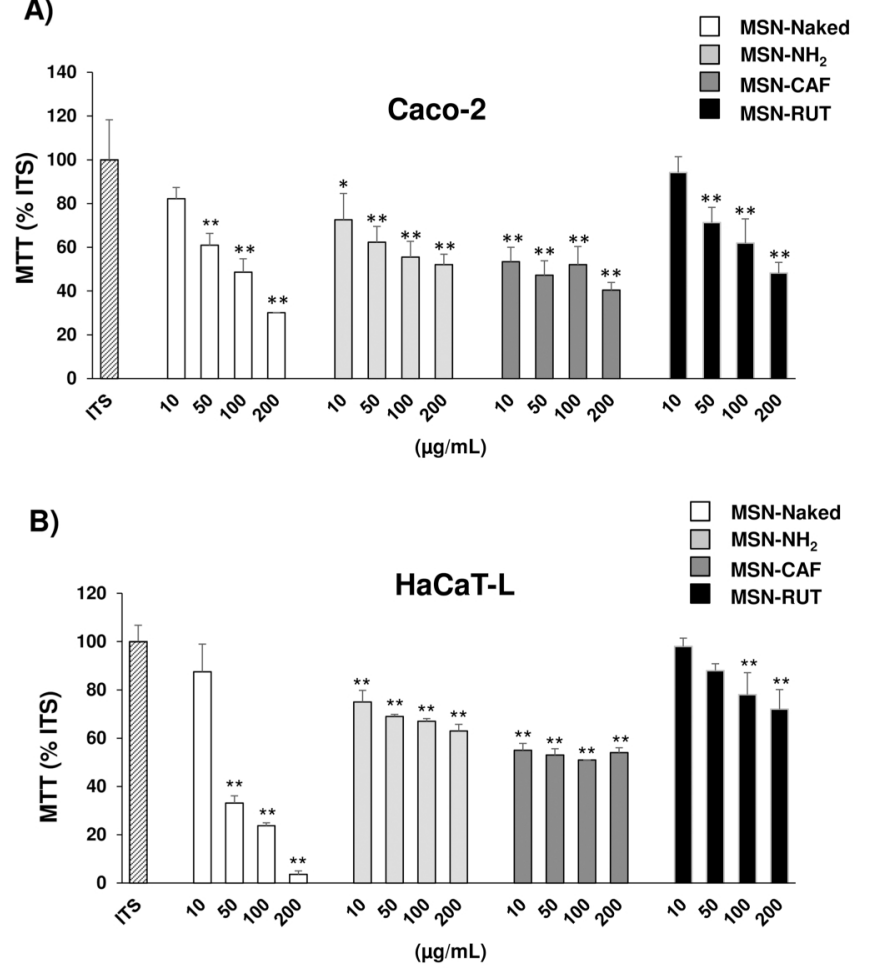

Figure 4. Cytotoxicity of nanoparticles on Caco-2 (A) or HaCaT-L (B) cells after $24 \mathrm{~h}$ treatment. Caco-2 or HaCaT-L cells were seeded at a density of $5 \times 10^{4}$ cells per well on 96-well transparent microplates and allowed to settle during $24 \mathrm{~h}$. They were then treated with nanoparticles at indicated concentration in 1\% ITS medium for $24 \mathrm{~h}$. MTT assay was performed as described in the Experimental Section. The experiment presented is representative of several independent experiments. Medium with no nanoparticles (ITS) was set at $100 \%$. Statistical analysis comparing different concentration of MSNs to ITS condition is indicated.

higher). In fact, MSN-RUT appeared to be the least cytotoxic nanoparticles, the lowest dose giving a value not significantly different from that of ITS control. Then, grafting of rutin on MSNs gave a better protection than that provided by the amino-propyl arm (alone or bonded to caffeic acid) against cytotoxic effects. Equivalent concentrations of free caffeic acid or free rutin, when tested in the same conditions, did not exhibit cytotoxic effects on both $\mathrm{HaCaT}-\mathrm{L}$ or Caco-2 cells (Figure S4), confirming that cytotoxicity effects observed in our study were rather due to the chemical nature of the silica nanoparticles.

Effects of MSNs Functionalization with Antioxidants on ROS Generation in Both Caco-2 and HaCaT-L Cell Lines. As described in the preceding section, nanoparticles were shown to have more or less cytotoxic effects, depending on dose and cell type used. In fact, doses from which cellular effects were the most interesting to analyze were in the range of $10-200 \mu \mathrm{g} / \mathrm{mL}$, partly because of the difference between naked and grafted particles. Owing to these considerations, pertinent measurement of ROS had to be normalized by MTT values, in order to give the true response of living cells. Figure 5 shows the normalized ROS level of Caco- 2 or HaCaT-L cell lines after a $24 \mathrm{~h}$ treatment with nanoparticles. In Caco-2 cells, the prominent result was the absence of ROS induction after treatment with MSN-RUT, whereas ROS level was increased by treatment with other nanoparticles. In HaCaT-L cells, treatment with naked nanoparticles led to a strong induction of 

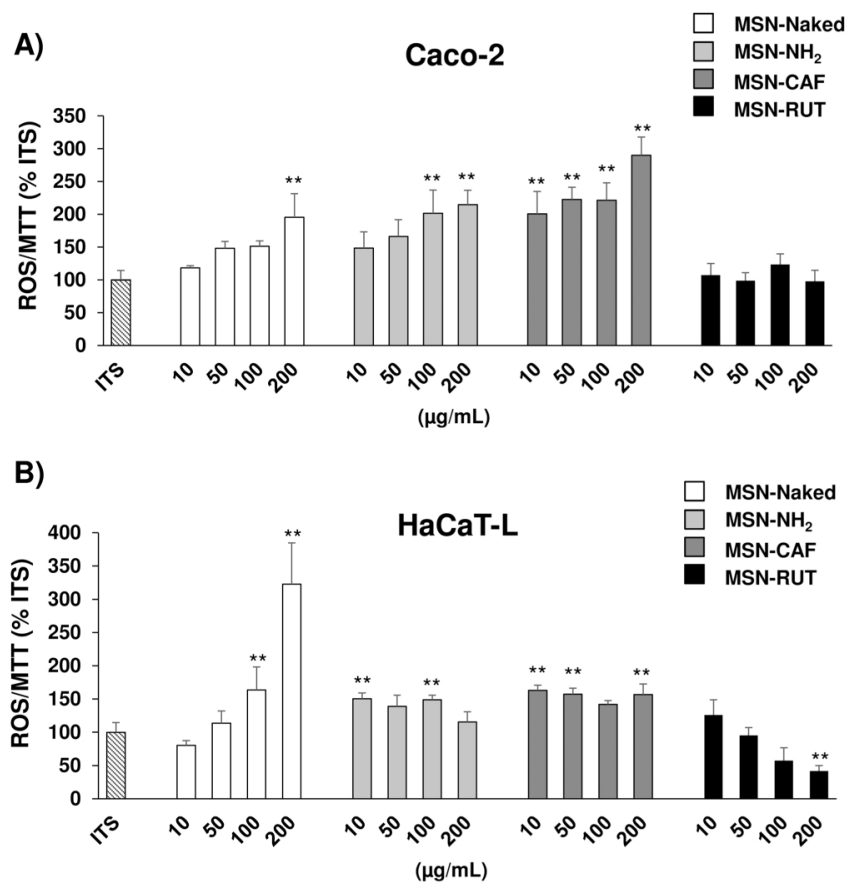

Figure 5. Intracellular ROS induction in Caco-2 or HaCaT-L cells after $24 \mathrm{~h}$ of nanoparticles treatment. Caco- 2 or HaCaT-L cells were seeded at a density of $5 \times 10^{4}$ cells per well in black-walled 96-well microplates with transparent bottom and were allowed to settle for 24 $\mathrm{h}$ in DMEM-F12 medium. Cells were then treated either with nanoparticles at indicated concentrations or with medium without nanoparticles (termed ITS). Normalized ROS measurement was performed by using the DCFH-DA fluorescent probe, as described in the Experimental Section. Medium without nanoparticles is set at $100 \%$. Statistical analysis comparing different concentrations of MSNs to ITS condition is indicated.

ROS level especially for the highest dose. Conversely, treatment with MSN-RUT led to a dose-dependent inhibition of this level. Together these results indicate that MSN-RUT particles had the best protective effect despite the higher content of caffeic acid molecules grafted on MSN-CAF. Equivalent concentrations of free caffeic acid or free rutin, when tested in the same conditions, did not change intracellular ROS levels (Figure S5). Interpretation of these results concerning grafted or free antioxidants effects on ROS production is given in the Discussion section.

Results showed that effects of grafted antioxidant molecules MSNs were clearly different in both cell lines. In Caco-2 cells, only grafted rutin was able to counteract the ROS increase induced by naked MSNs, while in HaCaT-L cells both, caffeic acid and rutin, could have such effect, that of rutin being dose dependent and more efficient at high concentration. At nanoparticles concentration of $200 \mu \mathrm{g} / \mathrm{mL}$, the level of ROS in HaCaT-L was diminished by a factor 2 in the presence of grafted caffeic acid (MSN-CAF) and by a factor 7.7 in the presence of grafted rutin (MSN-RUT). One can hypothesize that such differences in efficiency, when comparing MSNs grafted with caffeic acid or rutin, might reflect corresponding differences in their antiradical capacities observed by using ORAC assay.

Finally, we found that naked MSNs induced a dosedependent increase of intracellular ROS that was associated with a parallel increase of cellular mortality, these effects being more pronounced in HaCaT-L than in Caco-2 cells. The higher level of cell death that was observed in HaCaT-L may perhaps simply be a direct consequence of the higher level of ROS produced in these cells.

Since Nrf2 pathway has been shown to play a central role in the complex interplay between ROS generation and cellular defense mechanisms, its MSN-induced activation was carefully investigated in this study.

Generation and Characterization of a Stable AREDriven Reporter HaCaT-L Cell Line. In order to study skin effects of nanoparticles, especially those linked to protection against oxidative stress, we generated a stable ARE (antioxidant response element)-driven reporter $\mathrm{HaCaT}-\mathrm{L}$ cell line that was built by using a similar strategy to that developed by Emter. ${ }^{64}$ This stable cell line was designed for the screening of Nrf2 signaling pathway inducers. As described in the Experimental Section, 8-fold repeat of antioxidant response elements were placed in front of the luciferase gene, and stably transfected in HaCaT-L cells. As a first test, the effect of the tert-butylhydroquinone (tBHQ) compound, an antioxidant known to induce strong activation of the Nrf2 signaling pathway, was investigated on our HaCaT-L cell line. In these cells, the induction factor was respectively 3 and 6.6 after 8 or $24 \mathrm{~h}$ of treatment with $20 \mu \mathrm{M}$ tBHQ (Figure 6A) with no changes in cellular viability (not shown). After $24 \mathrm{~h}$ of treatment with $\mathrm{tBHQ}$, the luciferase activity was raised in a dose dependent fashion (maximum induction factor: 11.2) without significant effect on cellular viability assessed by MTT (Figure 6B ,C).

In a second step, to make sure that luciferase induction was a direct consequence of the Nrf2 signaling pathway activation, mRNA expression of Nrf2 and Keap1, as well as two target genes for the Nrf2 cofactor (HO-1 and NQO-1) were assessed. The Nrf2 or Keap 1 mRNA levels were not changed after $24 \mathrm{~h}$ treatment with $\mathrm{tBHQ}$ (Figure 6D), whereas those for HO-1 or NQO-1 were increased respectively by a factor of 2.54 and 2.52 . These results suggest that this Nrf2 signaling pathway activation was not a consequence of a transcriptional regulation of Nrf2 or Keap1 gene, but rather a consequence of the Nrf2 protein nuclear shuttling.

In order to assess the effect of free antioxidant ligands on luciferase expression in HaCaT-L cells, dose response curves with antioxidant molecules were performed. Until $30 \mu \mathrm{M}$ for rutin and $200 \mu \mathrm{M}$ for caffeic acid, no induction of luciferase expression nor cytotoxicity (assessed by MTT) were observed (Figure 7B,C). By contrast, we and others found that quercetin is a strong inducer of $\mathrm{Nrf2}$ (Figure 7A) ${ }^{65}$ More precisely, in the range of $1-30 \mu \mathrm{M}$, free quercetin was able to induce luciferase expression of HaCAT-L cells by a factor 19, together with the loss of $37 \%$ of the cells.

Effect of Nanoparticles on Nrf2 Signaling Pathway in HaCaT-L and Caco-2 Cells. By using the HaCaT-L tool, the Nrf2 response to nanoparticles treatment was then investigated. All the types of our nanoparticles induced an increase of normalized luciferase expression, indicating an activation of the $\mathrm{Nrf2}$ signaling pathway (Figure 8A). Interestingly, at a dose of $200 \mu \mathrm{g} / \mathrm{mL}, \mathrm{MSN}-\mathrm{RUT}$ and in a lesser extent MSN-naked, induced a very strong induction of $\mathrm{Nrf} 2$ in these cells (Figure 8A). Neither $\mathrm{MSN}-\mathrm{NH}_{2}$ nor MSN-CAF displayed a similar effect.

We then assessed the mRNA level variations of some players of the Nrf2 signaling pathway after a $24 \mathrm{~h}$ treatment with 200 $\mu \mathrm{g} / \mathrm{mL}$ of nanoparticles in both $\mathrm{HaCaT}-\mathrm{L}$ and Caco-2 cell lines (Figures $8 \mathrm{~B}$ and 9). In $\mathrm{HaCaT}-\mathrm{L}$ cell line (Figure $8 \mathrm{~B}$ ) a very high mRNA induction of the Nrf2 target HO-1 was also 
A)

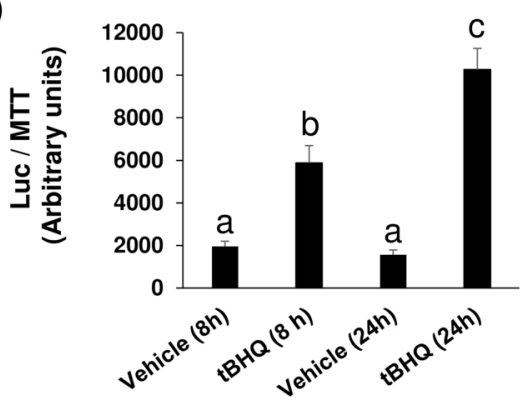

C)

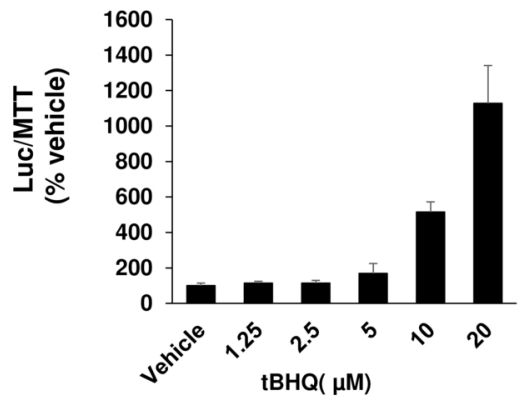

B)

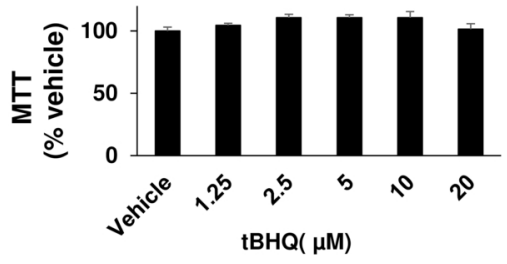

D)

HaCaT-L cells : incubation time $=24 \mathrm{~h}$

Vehicle

tBHQ $(20 \mu \mathrm{M})$
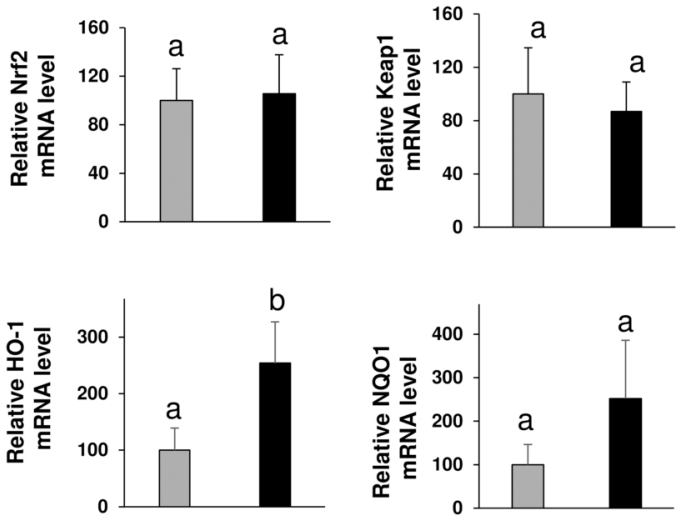

Figure 6. Characterization of HaCaT-L cells. HaCaT-L cells were seeded in 6-well transparent plates at a density of $5 \times 10^{4}$ cells per well and were allowed to settle for $24 \mathrm{~h}$ in DMEM-F12 medium as described in the "normalized luciferase assay" paragraph of the Experimental Section. After this period of time: (A) cells were then treated for either 8 or $24 \mathrm{~h}$ with $20 \mu \mathrm{M} \mathrm{tBHQ}$ or vehicle alone in DCC-medium; (B) cells were treated for $24 \mathrm{~h}$ with tBHQ (at indicated concentrations) or vehicle alone (DMSO) in DCC-medium. Then viability of cells was assessed by MTT assay as described in the Experimental Section; (C) cells were treated $24 \mathrm{~h}$ with indicated concentrations of tBHQ or vehicle alone in DCC-medium. Cells were then processed for "normalized luciferase assay" as described in the Experimental Section. Results are expressed as percent of vehicle condition; (D) cells were then incubated for $24 \mathrm{~h}$ with either $20 \mu \mathrm{M}$ tBHQ or vehicle alone in DCC-medium. Nrf2, Keap1, HO-1, and NQO1 mRNA were assessed by qPCR as described in the Experimental Section. Middle and bottom, normalized luciferase activity assay was performed as described in the Experimental Section. Statistical analysis relative to ITS condition is indicated.

observed after treatment with MSN-RUT and to a lesser extent with NP-Naked, confirming the above results obtained with luciferase measurements. In Figure $8 \mathrm{C}$, the effects on mRNA expression of either $44 \mu \mathrm{M}$ of free rutin or $880 \mu \mathrm{M}$ of free caffeic acid were also investigated in HaCaT-L cells. As already stated, these concentrations are equivalent to that of rutin or caffeic acid grafted on $200 \mu \mathrm{g} / \mathrm{mL}$ of MSNs (calculated on the basis of thermogravimetric data). No significant variation of Nrf2 and a modest increase of Keap1 mRNA were observed after $24 \mathrm{~h}$ incubation with either $880 \mu \mathrm{M}$ of free caffeic acid or $44 \mu \mathrm{M}$ of free rutin. Despite these effects observed on Keap 1 mRNA, this pathway appeared to be moderately activated since both levels of HO-1 and NQO1 mRNA were increased, the effect being more pronounced for caffeic acid whose concentration used in this experiment was quite high.

In Caco-2 cells, only a modest induction of HO-1 after treatment with $200 \mu \mathrm{g} / \mathrm{mL}$ of MSN-RUT was observed (Figure 9, right side), indicating again clear differences between Caco-2 and $\mathrm{HaCaT}$ cell lines. The effect on mRNA expression of a rutin concentration, which corresponds to that of rutin grafted on $200 \mu \mathrm{g} / \mathrm{mL}$ of MSN-RUT (calculated on the basis of thermogravimetric data), was also investigated in Caco-2 cells
(Figure 9 left side). None of the mRNA expressions were changed after a $24 \mathrm{~h}$ treatment with $44 \mu \mathrm{M}$ of free rutin. In addition to results of Figure 7 on HaCaT-L cells, these results suggest that up to $44 \mu \mathrm{M}$, free rutin does not activate the Nrf2 pathway. In both cell lines, after a $24 \mathrm{~h}$ treatment with $200 \mu \mathrm{g} /$ $\mathrm{mL}$ of MSN-RUT, Nrf2 mRNA level was raised (factor 2.6 in HaCaT-L and 1.7 in Caco-2 cells), whereas the inhibitor Keap1 did not change significantly. Same treatment with $200 \mu \mathrm{g} / \mathrm{mL}$ of MSN-naked in HaCaT-L cells led to modest increases of both Nrf2 (factor 1.4) and Keap1 (factor 1.2).

In HaCaT-L cells, treatment with MSN-CAF or MSN-NH led only to a modest increase of luciferase level (Figure 8A) (with the highest levels of luciferase and HO-1 mRNA being observed for MSN-CAF (Figure 8A,B)). In HaCaT-L cells, The Nrf2 target NQO1 was not induced to the same extent than HO-1, whereas in Caco-2 cells similar induction (albeit lower) factors were observed, suggesting an upper limit in NQO1 induction.

\section{DISCUSSION}

Contrary to other approaches that aimed to deliver antioxidant molecules noncovalently embedded into MSNs, we used 


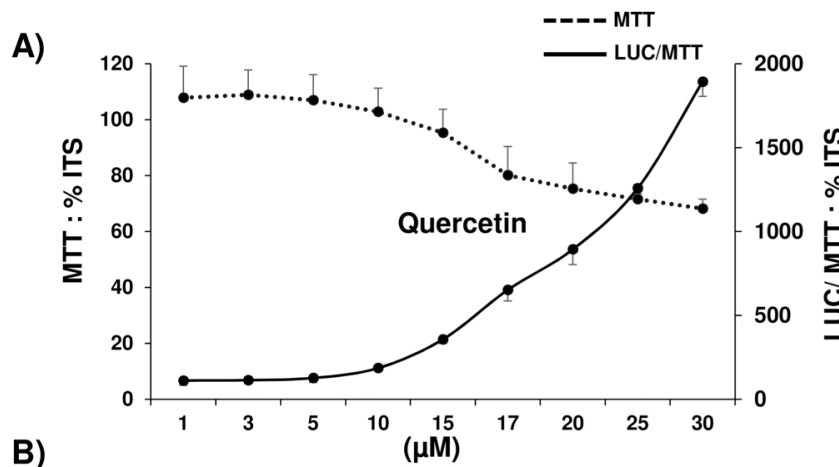

B)

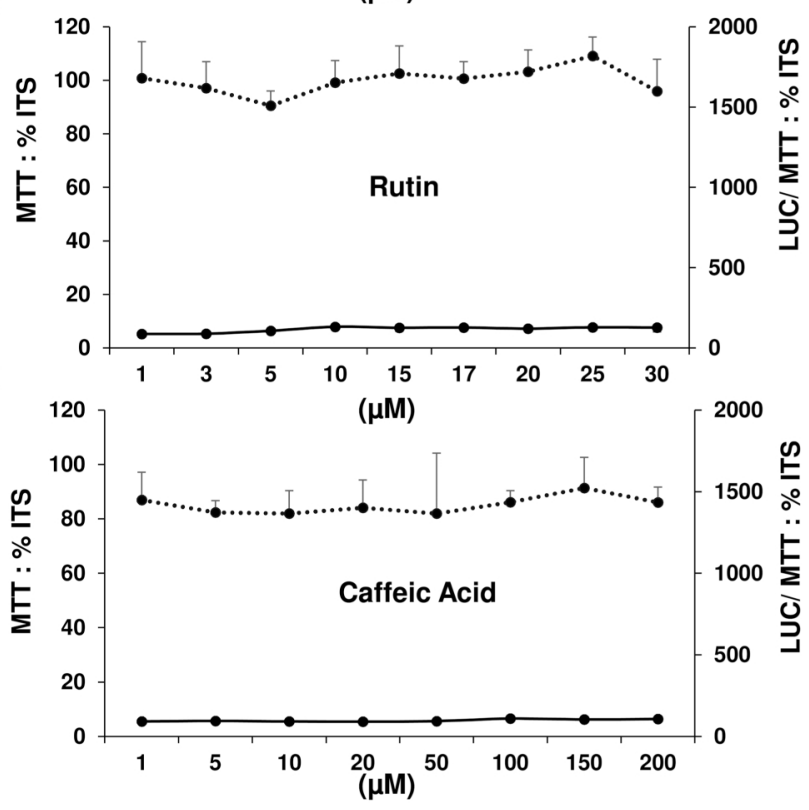

Figure 7. Effect of free antioxidant molecules on cell viability and luciferase expression in $\mathrm{HaCaT}-\mathrm{L}$ cells. $\mathrm{HaCaT}-\mathrm{L}$ cells were seeded at a density of $5 \times 10^{4}$ cells per well and allowed to settle $24 \mathrm{~h}$ in DMEM-F12 medium as described the "normalized luciferase assay" paragraph of the Experimental Section. Cells were then incubated for $24 \mathrm{~h}$ with (A) quercetin, (B) rutin, or (C) caffeic acid at indicated concentration in DCC-medium and were then processed for "normalized luciferase assay" as described in the Experimental Section. Vehicle was set at 100 .

covalently linked antioxidant molecules. It was then expected that, during the cellular treatment, antioxidant moiety would not be released into the cell, but rather, by remaining attached to the nanoparticle it could help to keep a low level of ROS as long as nanoparticles (free or with the corona of proteins) were in contact with the cell. By using ORAC assay, we confirmed that part of antiradical properties of antioxidant molecules were conserved in graft nanoparticles. When equivalent amounts of nanoparticles were compared, ORAC values indicated that antiradical function of MSN-RUT is higher (3.7 times) than that of MSN-CAF, whereas thermogravimetric analysis indicated that the amount (per mg of MSN) of caffeic acid is 20 times in excess, compared to that of rutin. Thus, when ORAC values corresponding to equivalent concentrations of free or grafted antioxidant molecules were compared (Figure $3 \mathrm{C}$ ), we found that only $1.3 \%$ of caffeic acid antioxidant activity was preserved against $67 \%$ in the case of rutin. In the light of the fact that catechol groups were conserved after coupling of caffeic acid, one can hypothesize that this antioxidant molecule, which is smaller than rutin, could penetrate more deeply into

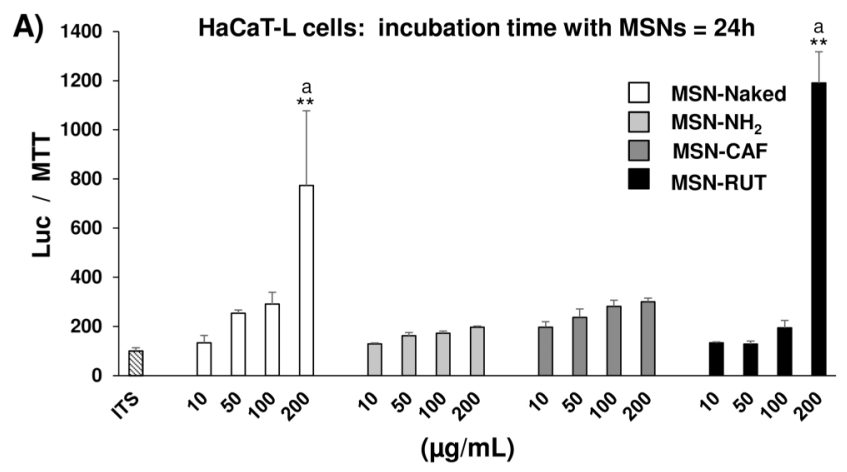

HaCaT-L cells: incubation time with $200 \mu \mathrm{g} / \mathrm{ml}$ MSNs $=24 \mathrm{~h}$

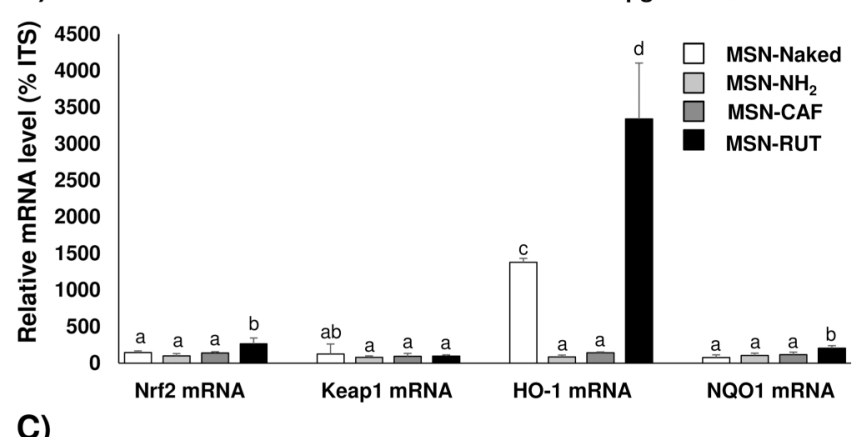

HaCaT-L cells: incubation time with free caffeic acid or rutin $\mathbf{= 2 4 h}$.

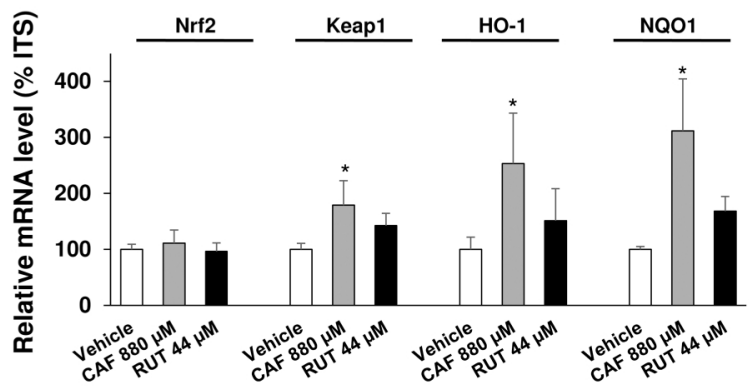

Figure 8. Effect of nanoparticles on Nrf2 signaling pathway in $\mathrm{HaCaT}$ L cells. (A) Luciferase activity of HaCaT-L cells: cells were seeded at a density of $5 \times 10^{4}$ cells per well and allowed to settle for $24 \mathrm{~h}$ in DMEM-F12 medium as described in the "normalized luciferase assay" paragraph of the Experimental Section. Cells were then treated for 24 $\mathrm{h}$ with either nanoparticles at indicated concentrations or with medium without nanoparticles (termed ITS). Cells were then processed for "normalized luciferase assay" as described in the Experimental Section. Medium without nanoparticles is set at $100 \%$. Statistical analysis comparing different concentration of MSNs to ITS condition is indicated. (B) mRNA expression analysis of HaCaT-L cells treated with $200 \mu \mathrm{g} / \mathrm{mL} \mathrm{NP}$ : cells were seeded in 6-well plates at a density of $1.5 \times 10^{6}$ cells per well and allowed to settle for $24 \mathrm{~h}$ in DMEM-F12 medium. Cells were then incubated for $24 \mathrm{~h}$ with either $200 \mu \mathrm{g} / \mathrm{mL}$ of nanoparticles or with medium without nanoparticles (ITS medium). Nrf2, Keap1, HO-1, and NQO1 mRNA were assessed by qPCR as described in the Experimental Section. Medium without nanoparticles is set at $100 \%$. For each mRNA analyzed, statistical significance concerning the mRNA level induced by grafted MSNs is indicated. (C) $\mathrm{HaCaT}$ cells were seeded and allowed to settle as described in panel B. They were then incubated for $24 \mathrm{~h}$ with indicated concentrations of caffeic acid, rutin, or with vehicle. Nrf2, Keap1, HO-1, and NQO1 mRNA were assessed by qPCR as described in the Experimental Section. Medium with vehicle was set at $100 \%$. Statistical significance when compared to vehicle condition is indicated.

the particle, being therefore less accessible and inefficient in triggering ROS or modulating cellular pathways. Conversely, rutin, which is a larger molecule, may have reacted nearer the 

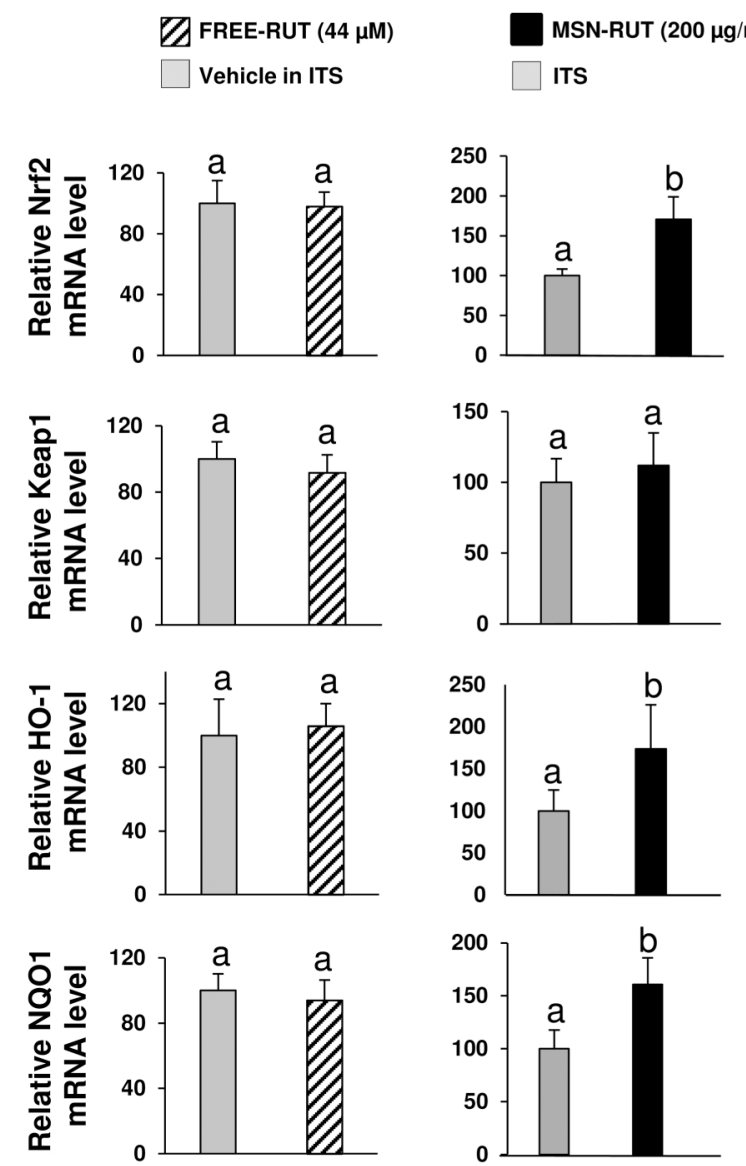

Figure 9. Effect of MSN-RUT or free rutin on Nrf2 signaling pathway in Caco- 2 cells. Histograms on the left: Caco-2 cells were seeded as described in Figure 8B and allowed to settle for $24 \mathrm{~h}$ in DMEM-F12 medium. They were then treated for $24 \mathrm{~h}$ with $44 \mu \mathrm{M}$ of free rutin or vehicle in ITS medium. Histograms on the right: In same seeding conditions, Caco-2 cells were treated with either $200 \mu \mathrm{g} / \mathrm{mL}$ of nanoparticles or with medium without nanoparticles (ITS medium). After RNA extraction and retrotranscription, Nrf2, Keap1, HO-1, and NQO1 mRNA were assessed by qPCR as described in the Experimental Section. Mediums with either vehicle or without nanoparticles were set at $100 \%$. Statistical analysis relative to ITS condition is indicated (letter index system).

surface of the particle, allowing a better interaction with radical moieties during ORAC assay. Moreover, as a result of the numerous hydroxyl groups of the sugar moieties, rutin may also have preferentially been adsorbed onto the surface of the MSN by hydrogen bonding with silanol groups. Despite a widespread use of silica NPs in the cosmetic industry, few studies analyzed their potential cytotoxicity. Such studies are nevertheless of crucial importance since it has been shown that silica nanoparticles could cause toxicity by the involvement of intracellular ROS generation. ${ }^{66-69}$ Furthermore, such ROS based toxicity mechanism has been evidenced for numerous types of nanoparticles, indicating a prominent role of these species. $^{70,71}$ In our study, we also found that naked MSNs induced a dose-dependent increase of intracellular ROS in Caco- 2 cells and more importantly in HaCaT-L cells. This ROS increase was associated with a parallel increase of cellular mortality, and again, HaCaT-L cells were more affected than Caco- 2 cells. This could simply be a direct consequence of the higher level of ROS produced in these cells.
Equivalent concentrations of free rutin or free caffeic acid did not exhibit significant effects on ROS production in the context of our experimental protocol. In that case, the antiradical effect of free antioxidants did not change significantly the basal low level of ROS, despite an increase of antioxidant enzymes levels observed in Figure 8C. Conversely, when grafted on MSNs, they operate by counteracting the high ROS production that is probably inherently induced by the silica part of nanoparticles, leading this time to measurable inhibitory effects. However, depending on the particle concentration used, such ROS reduction is obtained in a proportion that is difficult to predict (sum of two opposite effects), giving ROS levels that could appear dose dependent or not (Figure 5B). In the case of MSN-RUT particles, which elicit a very strong induction of the Nrf2 pathway (also evident at the mRNA level), the inhibitory effect on ROS generation was much more important and appears to be dose dependent.

The effect of antioxidant grafted MSNs was clearly different in both cell lines. In Caco- 2 cells, only grafted rutin was able to counteract the ROS increase induced by naked MSNs, while in $\mathrm{HaCaT}-\mathrm{L}$ cells both caffeic acid and rutin could have such effect, that of rutin being dose dependent and more efficient at high concentration. At nanoparticle concentration of $200 \mu \mathrm{g} /$ $\mathrm{mL}$, the level of ROS in HaCaT-L was diminished by a factor 2 in the presence of grafted caffeic acid (NP-CAF) and by a factor 7.7 in the presence of grafted rutin (NP-RUT). Such differences in efficiency might reflect corresponding differences in their antiradical capacities observed by using ORAC assay. However, other mechanisms, like antioxidant enzyme induction following $\mathrm{Nrf} 2$ pathway activation, could also operate. It has indeed been established that antioxidant compounds, and among them polyphenolic ones, could strongly induce the cytoprotective Nrf2 pathway. However, the precise mechanism of such signal transduction appears complex and involved several phases. ${ }^{48}$ Concerning quercetin, the study of Tanigawa showed that it could activate $\mathrm{Nrf} 2 / \mathrm{ARE}$-mediated NQO1 expression through multiple pathways including: induction of Nrf2 expression, mRNA and protein level, stabilization of Nrf2 protein through inhibition of ubiquitination, and reduction of Keap 1 steady state by modification of the protein. ${ }^{72} \mathrm{We}$ and others found that quercetin is a strong inducer of Nrf2 (Figure $7 \mathrm{~A}) .{ }^{65}$ It is worthy to note that free rutin does not induce significantly the Nrf2 pathway, despite the fact that this molecule contains the quercetin motif, indicating that at a molecular level, subtle differences in structural determinants are essential for such activation. Moreover, we observed that 880 $\mu \mathrm{M}$ of free caffeic acid, which is the equivalent concentration that corresponds to $200 \mu \mathrm{g} / \mathrm{mL}$ of MSN-CAF, was able to induce HO-1 and NQO1 significantly (Figure 8C), as well as luciferase activity (not shown), contrary to lower concentrations like those reported in Figure 7 . Here again, the fact that $200 \mu \mathrm{g} / \mathrm{mL}$ of MSN-CAF have lost the ability to induce these enzymes (Figure 8B) could be explained by the fact that caffeic acid might be grafted sufficiently deeply into the MSNs and then unable to interact with cellular machinery. However, in $\mathrm{HaCaT}$ cells, free rutin led to a modest increase of HO- 1 and NQO-1 (Figure 8C), whereas an equivalent concentration of bound rutin to MSNs elicits a strong $\mathrm{OH}-1$ but still a modest NQO-1 response (Figure $8 \mathrm{~B}$ ). These results suggest again that the cellular responses induced by either bound or free rutin could be very different. This might be a consequence of the presence of the silica part of MSN-RUT that induces per se a response that overlaps that of rutin, but with a different set of 
induced genes. Consequently, the effect of free or bound rutin on the steady state of intracellular ROS level that is obtained after these enzyme inductions could also be very different.

In our study, it appeared that $200 \mu \mathrm{g} / \mathrm{mL}$ of both MSNNaked and MSN-RUT were able to strongly activate the Nrf2 pathway through the induction of both the luciferase expression and, in a comparable extent, the expression of HO-1 mRNA (Figure 10). In the literature, it was shown that Nrf2 pathway

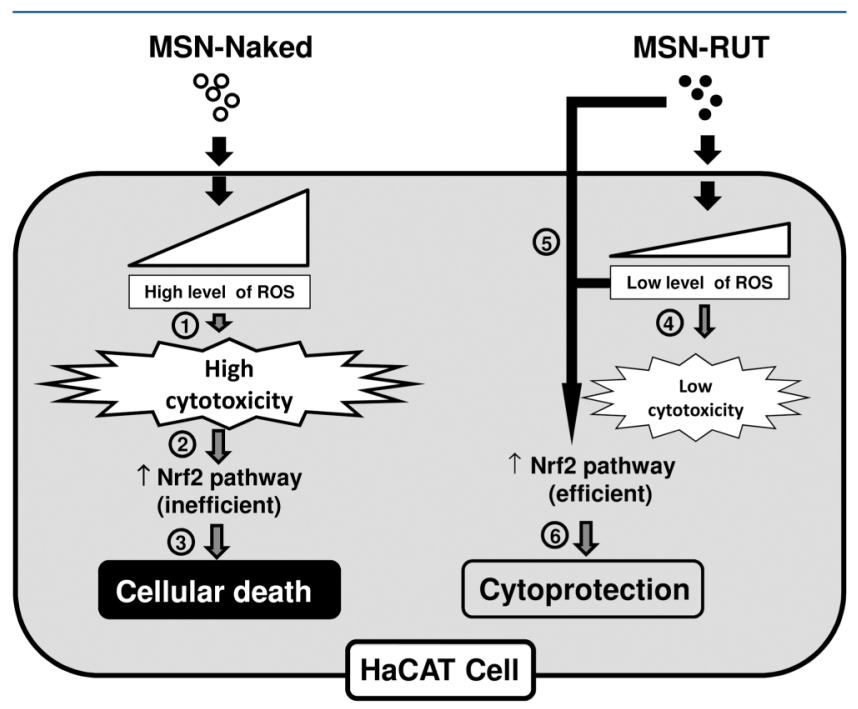

Figure 10. Diagram showing the contrasting effects of MSN-naked and MSN-RUT on HaCaT-L cell line. In keratinocyte (HaCaT-L) cell line, effects of MSN-naked and MSN-RUT were clearly different. MSN-naked induced a high ROS level that appeared cytotoxic for cells (arrow 1). In that case, the Nrf2 induction pathway, which might simply be a consequence of that ROS effect (arrow 2), would just be an attempt to strengthen the repairing processes (arrow 3) that occurred before cellular death. Conversely, the protecting effect of grafted rutin on MSNs initially led to a lower level of ROS, which by consequence diminished the level of cytotoxicity (arrow 4). In that case, both MSN-RUT and low level of ROS (arrow 5) were able to induce an efficient $\mathrm{Nrf} 2$ response associated with a reduced level of cellular death (arrow 6).

was activated more efficiently by low doses than by very high levels of ROS. ${ }^{73}$ This could be in accordance with our results in HaCaT-L cells since naked particles that induced a higher ROS level elicited a slightly lower Nrf2 response than MSN-RUT, which induced a lower ROS level. However, the Nrf2 pathway may also be activated by other phenomenon like apoptosis that is induced by cytotoxic molecules. Indeed, Lee et al. showed that the strong induction of $\mathrm{Nrf} 2$ induced by a high concentration of quercetin (up to $100 \mu \mathrm{M}$ ) was paralleled with the cell death level induced by such doses of antioxidant in malignant mesothelioma. ${ }^{65}$ Interestingly, Nrf2-targeting SiRNA experiments showed that, quercetin-induced upregulation of Nrf2 expression could lead to apoptosis inhibition. Taking these results into account, one can hypothesize that the very high Nrf2 level induced by NP-naked could be due to their cytotoxic effect, involving ROS generation, apoptotic mechanisms, or both.

MSN-RUT appears to be more effective and less cytotoxic than the naked particles. Moreover, it is unlikely that possible traces of unbound rutin could be responsible of the observed Nrf2 response since we showed that such response was not induced by even much higher doses (up to $30 \mu \mathrm{M}$ ) of free rutin (Figure 7). As quercetin was by itself able to induce a strong
Nrf2 response (Figure 7), one could then imagine that osidic bond of rutin was cleaved during incubation steps and quercetin moiety released. However, in our conditions, taking into account the chemical stability of bonded rutin as discussed above and the chemical stability of osidic bonds, such hypothesis of a spontaneous and quantitative break of the bond is unlikely. Another possibility concerned the enzymatic hydrolysis of the disaccharide bound. In human, rutinosides (compounds esterified to $\alpha$-L-rhamnosyl-( $1 \rightarrow 6)-\beta$-D-glucopyranoside) like rutin are cleaved by $\alpha$-L-rhamnosidase enzymes that are produced by microorganisms located in the microflora of the lower intestine. ${ }^{74,75}$ Since $\alpha$-L-rhamnosidase is not expressed in Caco-2 cells, quercetin glucoside and quercetin could not have been enzymatically released from possible small amount of free rutin that would have stuck to the nanoparticles. Moreover, enzymatic disruption of rutin bound to MSNs is also unlikely because of the specificity of such processes. Therefore, the high Nrf2 response induced by NP-RUT is more likely due to the effect of this modified particle on the whole and not simply a consequence of free quercetin that would have been released in the culture medium.

In our model system, we have not addressed the problem of grafted MSNs uptake into cells, but it is generally accepted that endocytosis is the major route of entry. ${ }^{76}$ Indeed, it has been shown that after topical application on skin silica NPs were able to penetrate into and pass through the skin. ${ }^{68} \mathrm{~A}$ necropsy analysis made by Ryu showed that topical application of silica NPs up to $2000 \mathrm{mg} / \mathrm{kg}$ on rat skin did not result in apparent internal organ injury or weight changes. ${ }^{77}$

In conclusion, we found that in $\mathrm{HaCaT}$ cells, high doses of MSN-naked induced a high level of ROS associated with high level of cytotoxicity, suggesting a direct or indirect involvement of ROS in such toxicity. Conversely, high doses of MSN-RUT were associated with lower levels of ROS and cellular death, yet associated with a very high level of Nrf2. Consequently, one can hypothesize that high level of Nrf2 induced by MSN-naked might be a consequence of the cell damages induced by ROS, whereas high level of Nrf2 induced by MSN-RUT might rather be a consequence of both the antioxidant properties of the bound rutin and low level of ROS. ${ }^{73}$ These differences between MSNs were, however, less clear in Caco- 2 cell line, showing an important cellular specificity in these nanoparticles responses. It is worthy to note that the cellular models used in this study involved immortalized cell lines. Besides, it is well-known that cancer cells possess variable ability of both, producing ROS and synthesizing antioxidant enzymes, leading to a steady state level of endogenous ROS that could be quite variable, depending on cell type. ${ }^{78}$ This might be the basis of the cellular specificity that was observed in our study. In order to get closer to the physiologic state of cells, the next step would then be to analyze the effects of our particles on primary mammalian cell cultures.

Altogether, these results revealed that grafting of rutin on MSNs could constitute a major improvement in the pharmacological or cosmetic use of the resulting particles. 


\section{AUTHOR INFORMATION}

\section{Corresponding Author}

*Phone: 334117598 92. Fax: 334675427 31. E-mail: eric. badia@umontpellier.fr.

\section{Notes}

The authors declare no competing financial interest.

\section{REFERENCES}

(1) Fleischer, C. C.; Payne, C. K. Nanoparticle-cell interactions: molecular structure of the protein corona and cellular outcomes. Acc. Chem. Res. 2014, 47, 2651-9.

(2) Nel, A. E.; Madler, L.; Velegol, D.; Xia, T.; Hoek, E. M.; Somasundaran, P.; Klaessig, F.; Castranova, V.; Thompson, M. Understanding biophysicochemical interactions at the nano-bio interface. Nat. Mater. 2009, 8, 543-57.

(3) Wu, Y. L.; Putcha, N.; Ng, K. W.; Leong, D. T.; Lim, C. T.; Loo, S. C.; Chen, X. Biophysical responses upon the interaction of nanomaterials with cellular interfaces. Acc. Chem. Res. 2013, 46, 78291.

(4) Mailander, V.; Landfester, K. Interaction of nanoparticles with cells. Biomacromolecules 2009, 10, 2379-400.

(5) Leroueil, P. R.; Hong, S.; Mecke, A.; Baker, J. R., Jr.; Orr, B. G.; Banaszak Holl, M. M. Nanoparticle interaction with biological membranes: does nanotechnology present a Janus face? Acc. Chem. Res. 2007, 40, 335-42.

(6) Hansen, S. F.; Michelson, E. S.; Kamper, A.; Borling, P.; StuerLauridsen, F.; Baun, A. Categorization framework to aid exposure assessment of nanomaterials in consumer products. Ecotoxicology 2008, 17, 438-47.

(7) Du, X.; Qiao, S. Z. Dendritic silica particles with center-radial pore channels: promising platforms for catalysis and biomedical applications. Small 2015, 11, 392-413.

(8) Liu, J.; Qiao, S. Z.; Hu, Q. H.; Lu, G. Q. Magnetic nanocomposites with mesoporous structures: synthesis and applications. Small 2011, 7, 425-43.

(9) Veneziano, R.; Derrien, G.; Tan, S.; Brisson, A.; Devoisselle, J. M.; Chopineau, J.; Charnay, C. One step synthesis of gold-loaded radial mesoporous silica nanospheres and supported lipid bilayer functionalization: towards bio-multifunctional sensors. Small 2012, 8, 3674-82.

(10) Yang, Y.; Li, J. Lipid, protein and poly(NIPAM) coated mesoporous silica nanoparticles for biomedical applications. Adv. Colloid Interface Sci. 2014, 207, 155-63.

(11) Mai, W. X.; Meng, H. Mesoporous silica nanoparticles: A multifunctional nano therapeutic system. Integrative biology: quantitative biosciences from nano to macro 2013, 5, 19-28.

(12) Sun, T.; Zhang, Y. S.; Pang, B.; Hyun, D. C.; Yang, M.; Xia, Y. Engineered nanoparticles for drug delivery in cancer therapy. Angew. Chem., Int. Ed. 2014, 53, 12320-64.

(13) Kim, J.; Kim, H. S.; Lee, N.; Kim, T.; Kim, H.; Yu, T.; Song, I. C.; Moon, W. K.; Hyeon, T. Multifunctional uniform nanoparticles composed of a magnetite nanocrystal core and a mesoporous silica shell for magnetic resonance and fluorescence imaging and for drug delivery. Angew. Chem., Int. Ed. 2008, 47, 8438-41.

(14) Wang, Y.; Gu, H. Core-shell-type magnetic mesoporous silica nanocomposites for bioimaging and therapeutic agent delivery. $A d v$. Mater. 2015, 27, 576-85.

(15) Knezevic, N. Z.; Durand, J. O. Large pore mesoporous silica nanomaterials for application in delivery of biomolecules. Nanoscale 2015, 7, 2199-209.

(16) Noureddine, A.; Lichon, L.; Maynadier, M.; Garcia, M.; GaryBobo, M.; Zink, J. I.; Cattoen, X.; Wong Chi Man, M. Controlled multiple functionalization of mesoporous silica nanoparticles: homogeneous implementation of pairs of functionalities communicating through energy or proton transfers. Nanoscale 2015, 7, 11444-52.

(17) Li, Z.; Barnes, J. C.; Bosoy, A.; Stoddart, J. F.; Zink, J. I. Mesoporous silica nanoparticles in biomedical applications. Chem. Soc. Rev. 2012, 41, 2590-605.

(18) Slowing, II; Vivero-Escoto, J. L.; Wu, C. W.; Lin, V. S. Mesoporous silica nanoparticles as controlled release drug delivery and gene transfection carriers. Adv. Drug Delivery Rev. 2008, 60, 1278-88.

(19) Meseguer-Olmo, L.; Ros-Nicolas, M.; Vicente-Ortega, V.; Alcaraz-Banos, M.; Clavel-Sainz, M.; Arcos, D.; Ragel, C. V.; ValletRegi, M.; Meseguer-Ortiz, C. A bioactive sol-gel glass implant for in vivo gentamicin release. Experimental model in Rabbit. J. Orthop. Res. 2006, 24, 454-60.

(20) Kortesuo, P.; Ahola, M.; Karlsson, S.; Kangasniemi, I.; Yli-Urpo, A.; Kiesvaara, J. Silica xerogel as an implantable carrier for controlled drug delivery-evaluation of drug distribution and tissue effects after implantation. Biomaterials 2000, 21, 193-8.

(21) Brevet, D.; Hocine, O.; Delalande, A.; Raehm, L.; Charnay, C.; Midoux, P.; Durand, J. O.; Pichon, C. Improved gene transfer with histidine-functionalized mesoporous silica nanoparticles. Int. J. Pharm. 2014, 471, 197-205.

(22) Fruijtier-Polloth, C. The toxicological mode of action and the safety of synthetic amorphous silica-a nanostructured material. Toxicology 2012, 294, 61-79.

(23) Sun, L.; Li, Y.; Liu, X.; Jin, M.; Zhang, L.; Du, Z.; Guo, C.; Huang, P.; Sun, Z. Cytotoxicity and mitochondrial damage caused by silica nanoparticles. Toxicol. In Vitro 2011, 25, 1619-29.

(24) Liang, H.; Jin, C.; Tang, Y.; Wang, F.; Ma, C.; Yang, Y. Cytotoxicity of silica nanoparticles on $\mathrm{HaCaT}$ cells. J. Appl. Toxicol. 2014, 34, 367-72.

(25) Trewyn, B. G.; Giri, S.; Slowing, II; Lin, V. S. Mesoporous silica nanoparticle based controlled release, drug delivery, and biosensor systems. Chem. Commun. 2007, 3236-45.

(26) Wang, Y.; Zhao, Q.; Han, N.; Bai, L.; Li, J.; Liu, J.; Che, E.; Hu, L.; Zhang, Q.; Jiang, T.; Wang, S. Mesoporous silica nanoparticles in drug delivery and biomedical applications. Nanomedicine 2015, 11, 313-27.

(27) Heikkila, T.; Santos, H. A.; Kumar, N.; Murzin, D. Y.; Salonen, J.; Laaksonen, T.; Peltonen, L.; Hirvonen, J.; Lehto, V. P. Cytotoxicity study of ordered mesoporous silica MCM-41 and SBA-15 microparticles on Caco-2 cells. Eur. J. Pharm. Biopharm. 2010, 74, 483-94.

(28) Kumar, V.; Kumari, A.; Guleria, P.; Yadav, S. K. Evaluating the toxicity of selected types of nanochemicals. Rev. Environ. Contam. Toxicol. 2012, 215, 39-121.

(29) Chen, Z.; Meng, H.; Xing, G.; Chen, C.; Zhao, Y.; Jia, G.; Wang, T.; Yuan, H.; Ye, C.; Zhao, F.; Chai, Z.; Zhu, C.; Fang, X.; Ma, B.; Wan, L. Acute toxicological effects of copper nanoparticles in vivo. Toxicol. Lett. 2006, 163, 109-20.

(30) Wang, J.; Zhou, G.; Chen, C.; Yu, H.; Wang, T.; Ma, Y.; Jia, G.; Gao, Y.; Li, B.; Sun, J.; Li, Y.; Jiao, F.; Zhao, Y.; Chai, Z. Acute toxicity and biodistribution of different sized titanium dioxide particles in mice after oral administration. Toxicol. Lett. 2007, 168, 176-85.

(31) Gunsolus, I. L.; Haynes, C. L. Analytical Aspects of Nanotoxicology. Anal. Chem. 2016, 88, 451-79.

(32) Berlier, G.; Gastaldi, L.; Sapino, S.; Miletto, I.; Bottinelli, E.; Chirio, D.; Ugazio, E. MCM-41 as a useful vector for rutin topical formulations: synthesis, characterization and testing. Int. J. Pharm. 2013, 457, 177-86.

(33) Berlier, G.; Gastaldi, L.; Ugazio, E.; Miletto, I.; Iliade, P.; Sapino, S. Stabilization of quercetin flavonoid in MCM-41 mesoporous silica: positive effect of surface functionalization. J. Colloid Interface Sci. 2013, 393, 109-18.

(34) Nday, C. M.; Halevas, E.; Jackson, G. E.; Salifoglou, A. Quercetin encapsulation in modified silica nanoparticles: potential use against $\mathrm{Cu}$ (II)-induced oxidative stress in neurodegeneration. J. Inorg. Biochem. 2015, 145, 51-64.

(35) Rahmanian, N.; Hamishehkar, H.; Dolatabadi, J. E.; Arsalani, N. Nano graphene oxide: a novel carrier for oral delivery of flavonoids. Colloids Surf., B 2014, 123, 331-8. 
(36) Sapino, S.; Ugazio, E.; Gastaldi, L.; Miletto, I.; Berlier, G.; Zonari, D.; Oliaro-Bosso, S. Mesoporous silica as topical nanocarriers for quercetin: characterization and in vitro studies. Eur. J. Pharm. Biopharm. 2015, 89, 116-25.

(37) Scalia, S.; Franceschinis, E.; Bertelli, D.; Iannuccelli, V. Comparative evaluation of the effect of permeation enhancers, lipid nanoparticles and colloidal silica on in vivo human skin penetration of quercetin. Skin pharmacology and physiology 2013, 26, 57-67.

(38) Sharma, S.; Ali, A.; Ali, J.; Sahni, J. K.; Baboota, S. Rutin: therapeutic potential and recent advances in drug delivery. Expert Opin. Invest. Drugs 2013, 22, 1063-79.

(39) Lin, W.; Huang, Y. W.; Zhou, X. D.; Ma, Y. In vitro toxicity of silica nanoparticles in human lung cancer cells. Toxicol. Appl. Pharmacol. 2006, 217, 252-9.

(40) Hao, N.; Yang, H.; Li, L.; Li, L.; Tang, F. The shape effect of mesoporous silica nanoparticles on intracellular reactive oxygen species in A375 cells. New J. Chem. 2014, 38, 4258-4266.

(41) Guo, C.; Xia, Y.; Niu, P.; Jiang, L.; Duan, J.; Yu, Y.; Zhou, X.; Li, Y.; Sun, Z. Silica nanoparticles induce oxidative stress, inflammation, and endothelial dysfunction in vitro via activation of the MAPK/Nrf2 pathway and nuclear factor-kappaB signaling. Int. J. Nanomed. 2015, $10,1463-77$.

(42) Li, L.; Liu, T.; Fu, C.; Tan, L.; Meng, X.; Liu, H. Biodistribution, excretion, and toxicity of mesoporous silica nanoparticles after oral administration depend on their shape. Nanomedicine 2015, 11, 191524.

(43) Foldbjerg, R.; Wang, J.; Beer, C.; Thorsen, K.; Sutherland, D. S.; Autrup, H. Biological effects induced by BSA-stabilized silica nanoparticles in mammalian cell lines. Chem.-Biol. Interact. 2013, 204, 28-38.

(44) Napierska, D.; Rabolli, V.; Thomassen, L. C.; Dinsdale, D.; Princen, C.; Gonzalez, L.; Poels, K. L.; Kirsch-Volders, M.; Lison, D.; Martens, J. A.; Hoet, P. H. Oxidative stress induced by pure and irondoped amorphous silica nanoparticles in subtoxic conditions. Chem. Res. Toxicol. 2012, 25, 828-37.

(45) Kehrer, J. P.; Klotz, L. O. Free radicals and related reactive species as mediators of tissue injury and disease: implications for Health. Crit. Rev. Toxicol. 2015, 45, 765-98.

(46) McCarthy, J.; Inkielewicz-Stepniak, I.; Corbalan, J. J.; Radomski, M. W. Mechanisms of toxicity of amorphous silica nanoparticles on human lung submucosal cells in vitro: protective effects of fisetin. Chem. Res. Toxicol. 2012, 25, 2227-35.

(47) Ma, Q. Role of nrf2 in oxidative stress and toxicity. Annu. Rev. Pharmacol. Toxicol. 2013, 53, 401-26.

(48) Niture, S. K.; Khatri, R.; Jaiswal, A. K. Regulation of Nrf2-an update. Free Radical Biol. Med. 2014, 66, 36-44.

(49) Taguchi, K.; Motohashi, H.; Yamamoto, M. Molecular mechanisms of the Keap1-Nrf2 pathway in stress response and cancer evolution. Genes to cells: devoted to molecular \& cellular mechanisms 2011, 16, 123-40.

(50) Tebay, L. E.; Robertson, H.; Durant, S. T.; Vitale, S. R; Penning, T. M.; Dinkova-Kostova, A. T.; Hayes, J. D. Mechanisms of activation of the transcription factor Nrf2 by redox stressors, nutrient cues, and energy status and the pathways through which it attenuates degenerative disease. Free Radical Biol. Med. 2015, 88, 108-146.

(51) Scapagnini, G.; Vasto, S.; Abraham, N. G.; Caruso, C.; Zella, D.; Fabio, G. Modulation of Nrf2/ARE pathway by food polyphenols: a nutritional neuroprotective strategy for cognitive and neurodegenerative disorders. Mol. Neurobiol. 2011, 44, 192-201.

(52) Suzuki, T.; Motohashi, H.; Yamamoto, M. Toward clinical application of the Keap1-Nrf2 pathway. Trends Pharmacol. Sci. 2013, $34,340-6$

(53) Kovac, S.; Angelova, P. R.; Holmstrom, K. M.; Zhang, Y.; Dinkova-Kostova, A. T.; Abramov, A. Y. Nrf2 regulates ROS production by mitochondria and NADPH oxidase. Biochim. Biophys. Acta, Gen. Subj. 2015, 1850, 794-801.

(54) Hosseinzadeh, H.; Nassiri-Asl, M. Review of the protective effects of rutin on the metabolic function as an important dietary flavonoid. Journal of endocrinological investigation 2014, 37, 783-8.
(55) Al-Dhabi, N. A.; Arasu, M. V.; Park, C. H.; Park, S. U. An up-todate review of rutin and its biological and pharmacological activities. EXCLI J. 2015, 14, 59-63.

(56) Li, Q.; Qiu, Y.; Mao, M.; Lv, J.; Zhang, L.; Li, S.; Li, X.; Zheng, $\mathrm{X}$. Antioxidant mechanism of Rutin on hypoxia-induced pulmonary arterial cell proliferation. Molecules 2014, 19, 19036-49.

(57) Kandaswami, C.; Middleton, E., Jr. Free radical scavenging and antioxidant activity of plant flavonoids. Advances in experimental medicine and biology 1994, 366, 351-76.

(58) Afanas'ev, I. B.; Dorozhko, A. I.; Brodskii, A. V.; Kostyuk, V. A.; Potapovitch, A. I. Chelating and free radical scavenging mechanisms of inhibitory action of rutin and quercetin in lipid peroxidation. Biochem. Pharmacol. 1989, 38, 1763-9.

(59) Ishimoto, H.; Tai, A.; Yoshimura, M.; Amakura, Y.; Yoshida, T.; Hatano, T.; Ito, H. Antioxidative properties of functional polyphenols and their metabolites assessed by an ORAC assay. Biosci., Biotechnol., Biochem. 2012, 76, 395-9.

(60) Napolitano, J. G.; Lankin, D. C.; Chen, S. N.; Pauli, G. F. Complete $1 \mathrm{H}$ NMR spectral analysis of ten chemical markers of Ginkgo biloba. Magn. Reson. Chem. 2012, 50, 569-75.

(61) Boukamp, P.; Petrussevska, R. T.; Breitkreutz, D.; Hornung, J.; Markham, A.; Fusenig, N. E. Normal keratinization in a spontaneously immortalized aneuploid human keratinocyte cell line. J. Cell Biol. 1988, $106,761-71$.

(62) Chantret, I.; Rodolosse, A.; Barbat, A.; Dussaulx, E.; BrotLaroche, E.; Zweibaum, A.; Rousset, M. Differential expression of sucrase-isomaltase in clones isolated from early and late passages of the cell line Caco-2: evidence for glucose-dependent negative regulation. J. Cell Sci. 1994, 107, 213-25.

(63) Turco, L.; Catone, T.; Caloni, F.; Di Consiglio, E.; Testai, E.; Stammati, A. Caco-2/TC7 cell line characterization for intestinal absorption: how reliable is this in vitro model for the prediction of the oral dose fraction absorbed in human? Toxicol. In Vitro 2011, 25, 1320.

(64) Emter, R.; Ellis, G.; Natsch, A. Performance of a novel keratinocyte-based reporter cell line to screen skin sensitizers in vitro. Toxicol. Appl. Pharmacol. 2010, 245, 281-90.

(65) Lee, Y. J.; Lee, D. M.; Lee, S. H. Nrf2 Expression and Apoptosis in Quercetin-treated Malignant Mesothelioma Cells. Mol. Cells 2015, $38,416-25$.

(66) Eom, H. J.; Choi, J. Oxidative stress of silica nanoparticles in human bronchial epithelial cell, Beas-2B. Toxicol. In Vitro 2009, 23, 1326-32.

(67) Kim, Y.-J.; Yu, M.; Park, H.-O.; Yang, S. Comparative study of cytotoxicity, oxidative stress and genotoxicity induced by silica nanomaterials in human neuronal cell line. Mol. Cell. Toxicol. 2010, $6,336-343$.

(68) Nabeshi, H.; Yoshikawa, T.; Matsuyama, K.; Nakazato, Y.; Matsuo, K.; Arimori, A.; Isobe, M.; Tochigi, S.; Kondoh, S.; Hirai, T.; Akase, T.; Yamashita, T.; Yamashita, K.; Yoshida, T.; Nagano, K.; Abe, Y.; Yoshioka, Y.; Kamada, H.; Imazawa, T.; Itoh, N.; Nakagawa, S.; Mayumi, T.; Tsunoda, S.; Tsutsumi, Y. Systemic distribution, nuclear entry and cytotoxicity of amorphous nanosilica following topical application. Biomaterials 2011, 32, 2713-24.

(69) Napierska, D.; Thomassen, L. C.; Lison, D.; Martens, J. A.; Hoet, P. H. The nanosilica hazard: another variable entity. Part. Fibre Toxicol. 2010, 7, 39.

(70) Shvedova, A. A.; Castranova, V.; Kisin, E. R.; Schwegler-Berry, D.; Murray, A. R.; Gandelsman, V. Z.; Maynard, A.; Baron, P. Exposure to carbon nanotube material: assessment of nanotube cytotoxicity using human keratinocyte cells. J. Toxicol. Environ. Health, Part A 2003, 66, 1909-26.

(71) Bartlomiejczyk, T.; Lankoff, A.; Kruszewski, M.; Szumiel, I. Silver nanoparticles - allies or adversaries? Ann. Agric. Environ. Med. 2013, 20, 48-54.

(72) Tanigawa, S.; Fujii, M.; Hou, D. X. Action of Nrf2 and Keap1 in ARE-mediated NQO1 expression by quercetin. Free Radical Biol. Med. 2007, 42, 1690-703. 
(73) Buelna-Chontal, M.; Zazueta, C. Redox activation of Nrf2 \& NF-kappaB: a double end sword? Cell. Signalling 2013, 25, 2548-57.

(74) Hollman, P. C.; Bijsman, M. N.; van Gameren, Y.; Cnossen, E. P.; de Vries, J. H.; Katan, M. B. The sugar moiety is a major determinant of the absorption of dietary flavonoid glycosides in man. Free Radical Res. 1999, 31, 569-73.

(75) Bang, S. H.; Hyun, Y. J.; Shim, J.; Hong, S. W.; Kim, D. H. Metabolism of rutin and poncirin by human intestinal microbiota and cloning of their metabolizing alpha-L-rhamnosidase from Bifidobacterium dentium. J. Microbiol. Biotechnol. 2015, 25, 18-25.

(76) Zhang, S.; Gao, H.; Bao, G. Physical Principles of Nanoparticle Cellular Endocytosis. ACS Nano 2015, 9, 8655-71.

(77) Ryu, H. J.; Seong, N. W.; So, B. J.; Seo, H. S.; Kim, J. H.; Hong, J. S.; Park, M. K.; Kim, M. S.; Kim, Y. R.; Cho, K. B.; Seo, M. Y.; Kim, M. K.; Maeng, E. H.; Son, S. W. Evaluation of silica nanoparticle toxicity after topical exposure for 90 days. Int. J. Nanomed. 2014, 9, $127-36$.

(78) Schieber, M.; Chandel, N. S. ROS function in redox signaling and oxidative stress. Curr. Biol. 2014, 24, R453-62. 